\title{
Innovation in India: A review of past research and future directions
}

Article in Asia Pacific Journal of Management · November 2015

DOI: $10.1007 /$ s10490-015-9442-z

CITATIONS

4

4 authors:

\section{Anil Nair}

Old Dominion University

34 PUBLICATIONS 629 CITATIONS

SEE PROFILE

\section{Stav Fainshmidt}

Florida International University

30 PUBLICATIONS 123 CITATIONS

SEE PROFILE
Orhun Guldiken

Manhattan College

10 PUBLICATIONS 7 CITATIONS

SEE PROFILE

Amir Pezeshkan

University of Baltimore

16 PUBLICATIONS 69 CITATIONS

SEE PROFILE

Some of the authors of this publication are also working on these related projects: 


\title{
Innovation in India: A review of past research and future directions
}

\author{
Anil Nair $^{1}$ • Orhun Guldiken ${ }^{1}$ - Stav Fainshmidt ${ }^{2}$. \\ Amir Pezeshkan ${ }^{3}$
}

Published online: 9 November 2015

(C) Springer Science+Business Media New York 2015

\begin{abstract}
The rapid economic growth that India enjoyed following the start of its economic reforms in 1991 has led to a growing scholarly interest in Indian organizations and management practices. In this paper, we bring together extant yet dispersed research on one important and salient element of Indian economic growth: innovation. We organize and review the substantive innovation research in India based on its scope and focus, and find that it has yielded unique insights about India's innovation systems and processes at both the institutional and firm levels. Three interesting trends emerge from this review of the literature. First, a growing body of research has started identifying innovation phenomena unique to India, such as "frugal innovation" and the related notion of "jugaad." Second, a discernible arc in Indian innovation research can be observed, that is, a shift from a focus on the role of the state to the role of MNEs and Indian businesses in innovation. Finally, unlike much innovation research elsewhere, there appears to be significant interest in innovation that serves the need of the
\end{abstract}

Orhun Guldiken, Stav Fainshmidt, and Amir Pezeshkan contributed equally to this work.

Anil Nair

anair@odu.edu

Orhun Guldiken

oguld001@odu.edu

Stav Fainshmidt

sfainshm@fiu.edu

Amir Pezeshkan

apezeshkan@ubalt.edu

1 Department of Management, Strome College of Business, Old Dominion University, Norfolk, VA 23529, USA

2 Department of Management and International Business, College of Business, Florida International University, Miami, FL 33174, USA

3 Department of Management \& International Business, Merrick School of Business, University of Baltimore, Baltimore, MD 21201, USA 
poor. We conclude with directions for future research on innovation within the Indian context.

Keywords Innovation $\cdot$ India $\cdot$ Review

"We originally came to India for the [low] cost. We stayed because of the quality, and now we're investing because of the innovation." Dan Scheinman, Former Senior Vice President of Cisco Systems' Media Solutions Group.

The rapid economic growth that India enjoyed following its economic reforms starting in 1991 has led to a growing scholarly interest in Indian organizations and management practices (Jain \& Sharma, 2013; Nair, Ahlstrom, \& Filer, 2007). This work has covered a wide range of topics and identified many unique aspects of Indian management in areas such as corporate governance, state and family firms, internationalization, venture capital, entrepreneurship, and innovation (e.g., George, RaoNicholson, Corbishley, \& Bansal, 2015; Lockett, Wright, Sapienza, \& Pruthi, 2002; Maheshwari \& Ahlstrom, 2004; Ramani \& Szirmai 2014). As the opening quote suggests, India's economic growth in the years following initial economic reforms was driven by low cost labor, particularly in information technology (IT), coupled with a surge in private sector and international investments subsequent to the removal of capital restrictions (Chari \& Banalieva, 2015). The labor cost arbitrage in IT and related industries spurred the initial exports and brought India much needed foreign exchange; indeed it was dwindling foreign exchange reserves that helped to precipitate the 1991 crisis and propelled financial and industrial reform (Li \& Nair, 2007) as it did in China over a decade earlier (Ahlstrom, Young, \& Nair, 2003; Harding, 1987). The initial increase in domestic and international investments allowed many sectors of the economy (e.g., communication, media) that were long starved for funds to catch up with latent demand and also upgrade technology and improve productivity. Despite many problems with corruption and stubborn poverty, India's growth has been swift and visible, increasing employment and income, while creating a vibrant middle class and introducing many modern management reforms (Ahlstrom, 2014; Cooke \& Saini, 2015; Gupta \& Wang, 2009).

Even with a recent slowdown in economic growth, India is already the fourth largest economy in the world in purchasing power parity terms (Giles, 2014), and is emerging as an innovation powerhouse (Forum for the Future, 2013). ${ }^{1}$ In fact, while India's innovation capacity has clearly contributed to its economic growth thus far (Fan, 2011), many now argue that India will have to rely even more on innovation and entrepreneurship (Chakraborty \& Kumar, 2013; Kulkarni, 2013), which are central to both firm and economic growth (Aghion \& Howitt, 1992, 1998; Ahlstrom, 2010a). Global clients have started demanding innovation in service delivery (Arora, Drev, \& Forman, 2009; Schrage, 2011), and some have noted (e.g., Anand \& Anand, 2009) that India's poverty and challenging social problems can be best solved by innovation

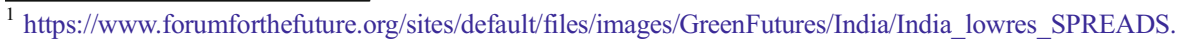
pdf
} 


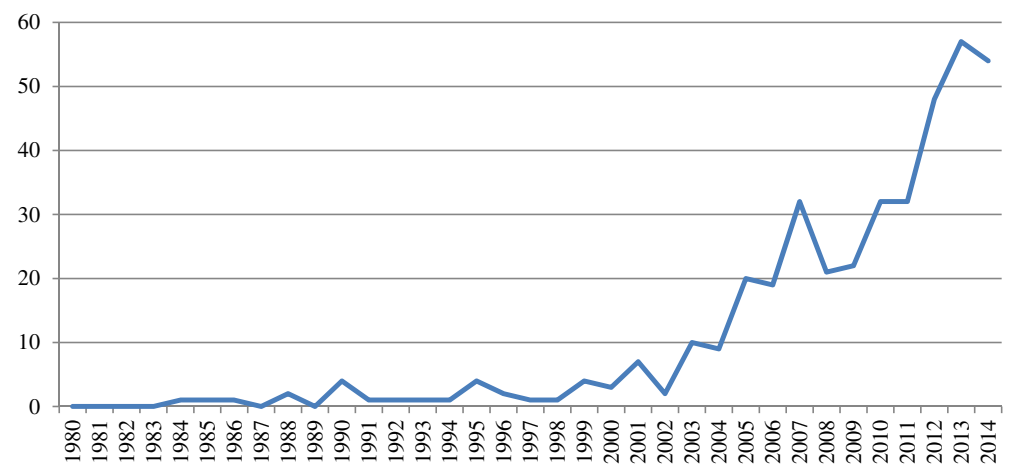

Fig. 1 Count of peer reviewed publications with "India" and "Innovation" in abstract (Based on search on $\mathrm{ABI} /$ Inform database)

that serves the poor (Alvarez, Barney, \& Newman, 2015; Bruton, Ahlstrom, \& Si, 2015; George et al., 2015).

India's capability to engage in low cost, unique innovation has already attracted the attention of academic and popular media (Govindarajan \& Ramamurti, 2013; Prabhu \& Jain, 2015; Prahalad \& Mashelkar, 2010; Rai, 2014). Cooper (2009) pointed out that the strong education system and the leadership in software and IT services may allow India to use a more innovation-based development path, instead of the low cost path followed by a number of other developing economies. A further indication of the critical importance of innovation to India's growth is the declaration of 2010-2020 as India's Innovation Decade by former Prime Minister Manmohan Singh.

Accordingly, because innovation is a topic particularly appropriate and interesting in the Indian context, our aim is to bring together the disparate literature investigating this phenomenon, better defining and thus facilitating its analysis (Ahlstrom, 2010b; Christensen, 2006). As Fig. 1 shows, over the past 20 years we have seen a rise in the number of books and articles focusing on innovation in the Indian context. Thus, in this paper we examine the themes in the various streams of management literature on Indian innovation, and identify issues that need to be addressed in future research to align and categorize the many developments in the field (Christensen, 2006).

While innovation has been studied by scholars from a range of areas such as marketing, economics, and engineering (e.g., Aghion \& Howitt, 1992, 1998; Govindarajan, Kopalle, \& Danneels, 2011; McCloskey, 2006, 2010, 2013; Mokyr, 1990; Petroski, 1994), our focus is primarily on Indian innovation research that has a management perspective (Christensen \& Raynor, 2003; Nair \& Ahlstrom, 2003). That is, our review includes research that addresses institutional, industry, and firm factors that drive (primarily) firm and product innovation. We do not review innovation research in general or specific streams which examine, for instance, individual adoption and diffusion of new product innovations. ${ }^{2}$ In the next section, we review existing definitions of innovation first to clarify the domain (e.g., Ahlstrom, Lamond, \& Ding, 2009; Christensen, 2006) and proceed to discussing the recent record of innovation in

\footnotetext{
${ }^{2}$ Excellent reviews of innovation research in other contexts and domains include Crossan and Apaydin (2010), Fagerberg, Mowery, and Nelson (2006), Gopalakrishnan and Damanpour (1997), Shafique (2013), and Wolfe (1994).
} 
India. Then we organize the existing literature into distinct streams. Finally, we suggest directions for future research.

\section{What is innovation?}

The word innovation has Latin origins, and began to appear in English language in the mid-1500s, and not unexpectedly, according to Google word-use graph, the usage of "innovation" has increased steadily ever since that time. Innovation means, "something new or different" (Webster). Economists, business scholars, and practitioners have long realized the value of innovation (e.g., Aghion \& Howitt, 1992, 1998; Ahlstrom, 2010a; Christensen \& Raynor, 2003; Mokyr, 1990); and while scholars may disagree about many aspects of innovation research and the findings may be inconsistent (e.g., Shafique, 2013; Wolfe, 1994), in general they view innovation as a net positive. Even before Schumpeter $(1934,1942)$ highlighted the role of (radical) innovation in creative destruction, writers such as Adam Smith had written about the role of technological improvements on society and factories and the role of innovators:

"All the improvements in machinery, however, have by no means been the invention of those who had occasion to use the machines. Many improvements have been made by the ingenuity of the makers of the machines, when to make them became the business of a peculiar trade; and some by that of those who are called philosophers or men of speculation, whose trade is not to do anything, but to observe everything; and who, upon that account, are often capable of combining together the powers of the most distant and dissimilar objects." (Smith, 1776: 18)

Despite this recognition of the relevance of innovation among early social scientists, it was the Austrian school led by Schumpeter that placed innovation at center stage in economics, and explicated its role in economic growth and industry transformation. Besides Schumpeter, several management scholars have also studied innovation and its impact on organizational outcomes. According to Thompson (1965: 36), innovation is the ". . . generation, acceptance and implementation of new ideas, processes, products or services."

Thompson's definition above, and a review of writings on innovation, point out that innovation is not limited to new products, but also includes new processes, organizational structures, and policies (Daft, 1982; Damanpour, 1991; Goswami \& Mathew, 2005). For instance, Baregheh, Rowley, and Sambrook (2009) analyzed the content of 60 different definitions of innovation from multiple disciplines and found many of them converging on the following: "Innovation is the multi-stage process whereby organizations transform ideas into new/improved products, services or processes, in order to advance, compete and differentiate themselves successfully in their marketplace" (1334).

Innovation is also rooted in societal institutions such as education systems, social interactions, culture, and labor market structure (Lam, 2000; Landes, 1998). That is, the structure, communication, and specialization of societies are a major driver of innovative activity (Damanpour, 1991; Kaplinsky, 2011; McCloskey, 2006, 2010). Not surprisingly, many use the term "innovation ecosystem" as a way to describe 
"collaborative arrangements through which firms combine their individual offerings into a coherent, customer-facing solution" (Adner, 2006: 98). Hence in this review, we focus on factors driving Indian innovation not just at the firm level, but the industrial and macro (institutional) levels as well.

\section{Innovation in India: A historical perspective}

India obtained independence from British rule in 1947. While Jawaharlal Nehru, India's first Prime Minister, was convinced about the need to embrace technology and innovation to spur India's economic growth, one prominent Indian freedom fighter and leader, Mahatma Gandhi, believed that it was (British) technology that had ruined the Indian economy, and therefore argued in favor of a low-technology, small scale industry-based development model that would emphasize employment for India's hundreds of millions. Though Nehru's vision prevailed and India adopted central planning with the state controlling many sectors of the Indian economy with a technology-intensive development policy (Ramesh, 1991), Gandhi's views were shared by many who harbored ambivalence or even a lingering suspicion of foreign businesses, technologies, and innovations (Basu, 2004).

In 1950, Nehru launched India on a path of economic development through a series of 5-year plans (Jalan, 1996). Even after his death, successive administrations continued with Nehru's policies. Over time, the public sector came to dominate India's economy, investing in big ticket items such as large factories, infrastructure, and tertiary educational institutions, while seeking to indigenize science and technology (Jain \& Kharbanda, 2003). Yet by the early 1980s, there was increasing concern that India's economic plans had not delivered the economic growth that had been achieved in East Asian economies such as Korea, Malaysia, and Singapore. Between 1950 and 1980, India realized an average real growth rate of only $3.5 \%$ (versus the typical $7 \%$ in East Asia) and the government-dominated and heavily-regulated system yielded inefficiencies, shortages, and corruption (Li \& Nair, 2007). It was only in 1991, when India faced a severe foreign exchange reserve crisis, that leaders introduced radical reforms to improve the economy. Prime Minister P. V. Narasimha Rao and Finance Minister (and later Prime Minister) Manmohan Singh used the crisis to justify the introduction of farreaching economic reforms that continued through the 1990s despite changes in administration and leadership (Bajpai, 2002).

The economic reforms have led to greater awareness about innovation among Indian businesses, academia, and government. While in the pre-reform era, suspicion of foreign technology, protection from foreign competition, and regulatory approvals for importing technology had isolated Indian businesses from innovation occurring elsewhere, opening the economy created imperatives for Indian businesses to adapt to the new competitive landscape and adopt new technologies and innovation for survival (Hitt, Keats, \& DeMarie, 1998). This is vital not only for generating new innovations, but also for adopting innovations from elsewhere and responding to the entry of innovative foreign competition into the domestic market.

One sign of the growing awareness of the importance of innovation is the annual competition run by India's National Innovation Foundation Innovation. At the first competition organized in 2000, more than 1600 entries were submitted, and the 
winning innovations included a bicycle made of bamboo and a water pulley that lets women take rest while drawing water from a well (Appropriate Technology, 2001). ${ }^{3}$ Moreover, R\&D expenditure made by Indian firms in many sectors has increased over the years, especially after reforms led to the entry of foreign firms. As a result, the number of patent applications and approvals has increased gradually over time (see Fig. 2).

In the past decade, several scholars (e.g., Govindarajan \& Ramamurti, 2011; Gupta \& Govindarajan, 2001; Khanna, 2013) have noted the growth of Indian entrepreneurship and innovations by Indian firms or multinational enterprises (MNEs) in India. Firms such as Tata, General Electric, Infosys, Selco, Bharti Airtel, Aravind, and Narayana Hrudalaya have been in the news for their novel offerings and disruptive innovations (Ahlstrom, 2010a; Li, 2013; Prahalad \& Mashelkar, 2010). For example, the Tata Electrical division designed a tamper evident electric meter. ${ }^{4}$ Tata also produced the Swach water filter line, which has brought potable water in large numbers in the developing world (Ahlstrom, 2010a). Dr. Reddy's lab developed Methyldopa, an inexpensive blood pressure reducing medication. Airtel's business model innovation involved the introduction of modularity, or outsourcing the operation and maintenance of network equipment, towers, lines, IT, and customer service so that it could focus on low cost service. In addition to its business model innovation, Airtel also engages in numerous product innovations. For instance, it recently introduced Song Catcher, where callers can adopt the ringtone of the person they are calling. Naryana Hrudyalaya's business model innovation offers low cost cardiac care by using patient families to offer post-operative care, while other Indian hospitals have recently been recognized for their innovative ways of serving the masses with world-class health care (Govindarajan \& Ramamurti, 2013).

\section{Literature on Indian innovation}

\section{Methodology}

We searched for articles containing the keywords "India*" and "innovation" in leading management journals that appear on widely cited journal listings such as Financial Times Top 45 Business Publications and The University of Texas at Dallas list. Our initial search found that the following journals had not published a significant number of articles on Indian innovation: Journal of Engineering and Technology Management, Strategic Management Journal, Academy of Management Journal, Academy of Management Review, Journal of Management, Journal of Management Studies, Organization Science, and Management Science. Thus, we broadened our search and queried for peer reviewed publications in the ABI/Informs database that had used the terms "India" and "innovation" in the abstract. This search yielded 530 articles. From this list we dropped articles that had a distinct practitioner focus or were not about innovation in India - for example, our query pulled up articles about Indiana, Native American Indians, or that had mentioned India in the abstract, but were about other emerging

\footnotetext{
3 http://nif.org.in/innovation/pulley_with_stopper/93, accessed Mar. 30, 2015.

${ }^{4} \mathrm{http} / /$ www.tata.com/company/articlesinside/Showcasing-outstanding-innovations
} 


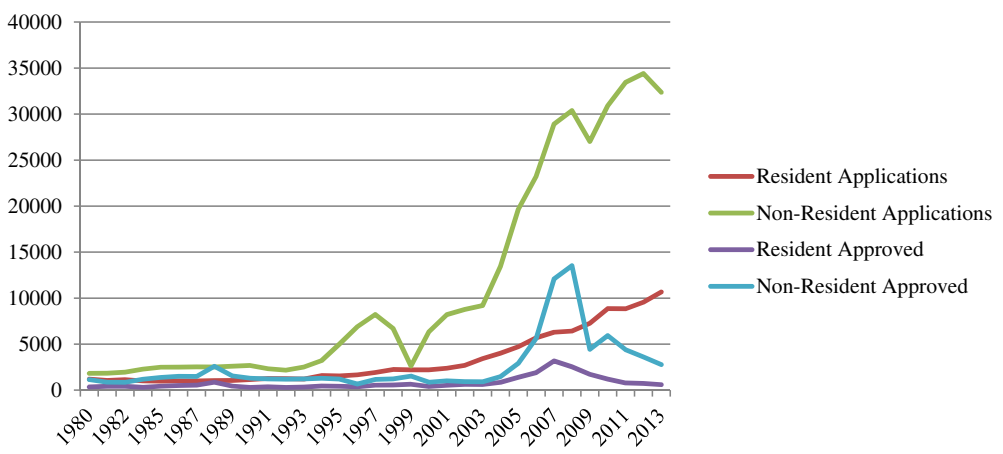

Fig. 2 India: Patents applications and approval (resident/non-resident) (Source: World Intellectual Property Organization, http://www.wipo.int/ipstats/en/\#data)

economies or one of the BRICs. ${ }^{5}$ Eliminating such articles resulted in 236 articles. Details of a representative sample of the articles included in our review are presented in Table 1.

Based on the articles included in our sample, we started to organize the literature into distinct clusters as a means to form an analytical framework for our review (Ginsberg \& Venkatraman, 1985). After several iterations of considering different dimensions (e.g., product versus service, technical versus administrative, simple versus complex, incremental versus radical; Damanpour, 1991; Downs \& Mohr, 1976; Gopalakrishnan \& Damanpour, 1997), we concluded that the literature could be parsimoniously organized using the following two dimensions: Micro versus macro and outcome versus process (also see Crossan \& Apaydin, 2010). Here, micro refers to studies that examine innovation at the firm-level, while macro means those examining innovation at the industry or national level. Outcome focused studies investigate innovation outcomes such as patents, products, and new business models, while process oriented studies examine processes such as information flows, routines, and learning in firms, industries or regions. The framework is shown in Table 2.

Clearly, some research will either fall outside of the categories or straddle the categories. For example, Mishra (2006) examined R\&D investments and patents and linked it to the market structure, patent laws, fiscal incentive system as well as firm specific factors such as organizational structure and culture. In this review, we ensure that we do not exclude papers that fall outside of our organizational framework. As changes in India's macro environment sparked its economic growth, FDI, and rise of Indian MNEs, we start with the macro perspective.

\section{Macro/outcome studies}

Within the macro-outcome quadrant, we include studies that have examined how institutional conditions and industry structures have impacted innovation outcomes. In recent years, India's economic liberalization program and the impact it had on innovation have attracted the attention of many scholars. Specifically, scholars have examined how increased FDI, entry of MNEs, and liberalized industry, trade, and

\footnotetext{
$\overline{{ }^{5} \text { Brazil, Russia, India, and China. }}$
} 


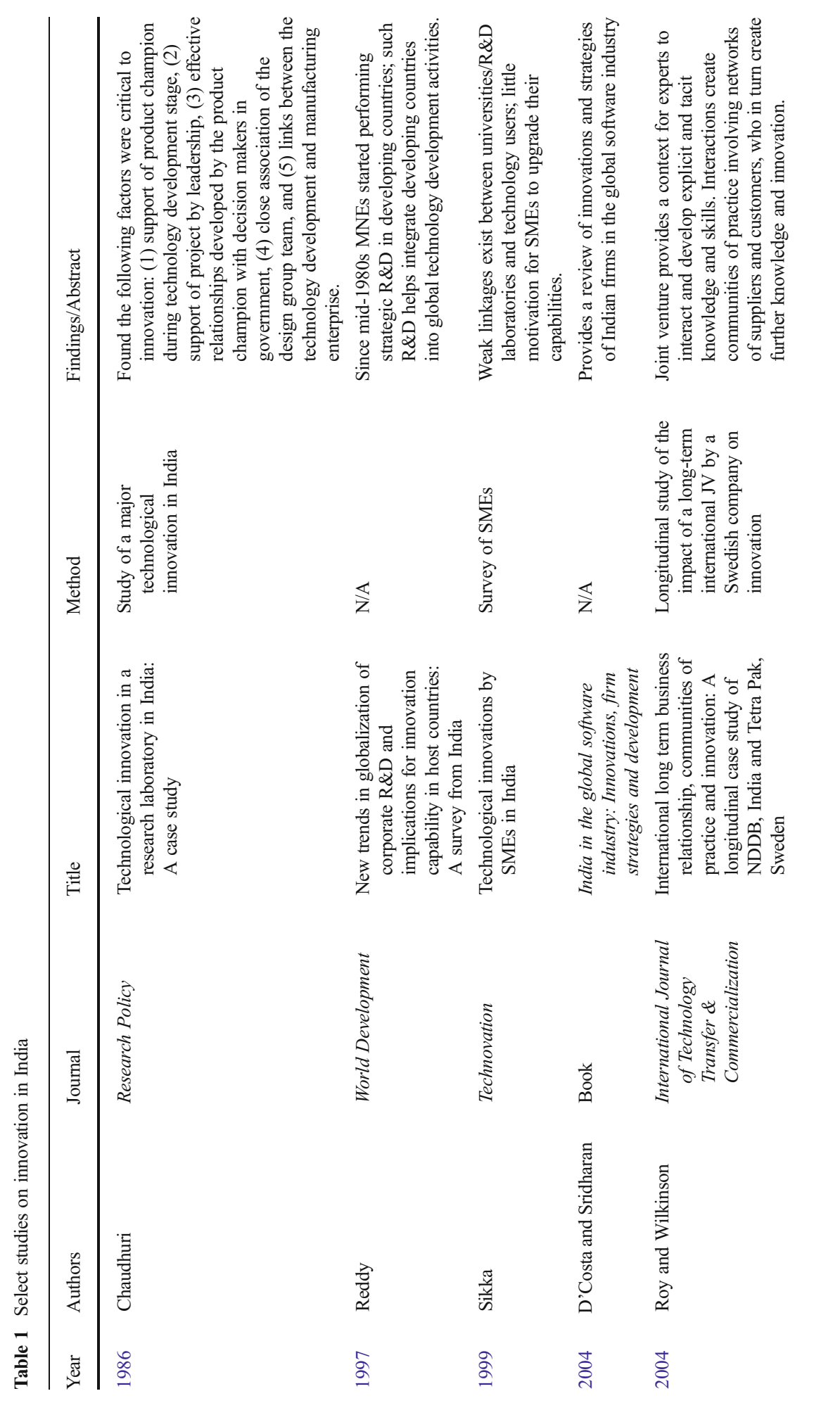




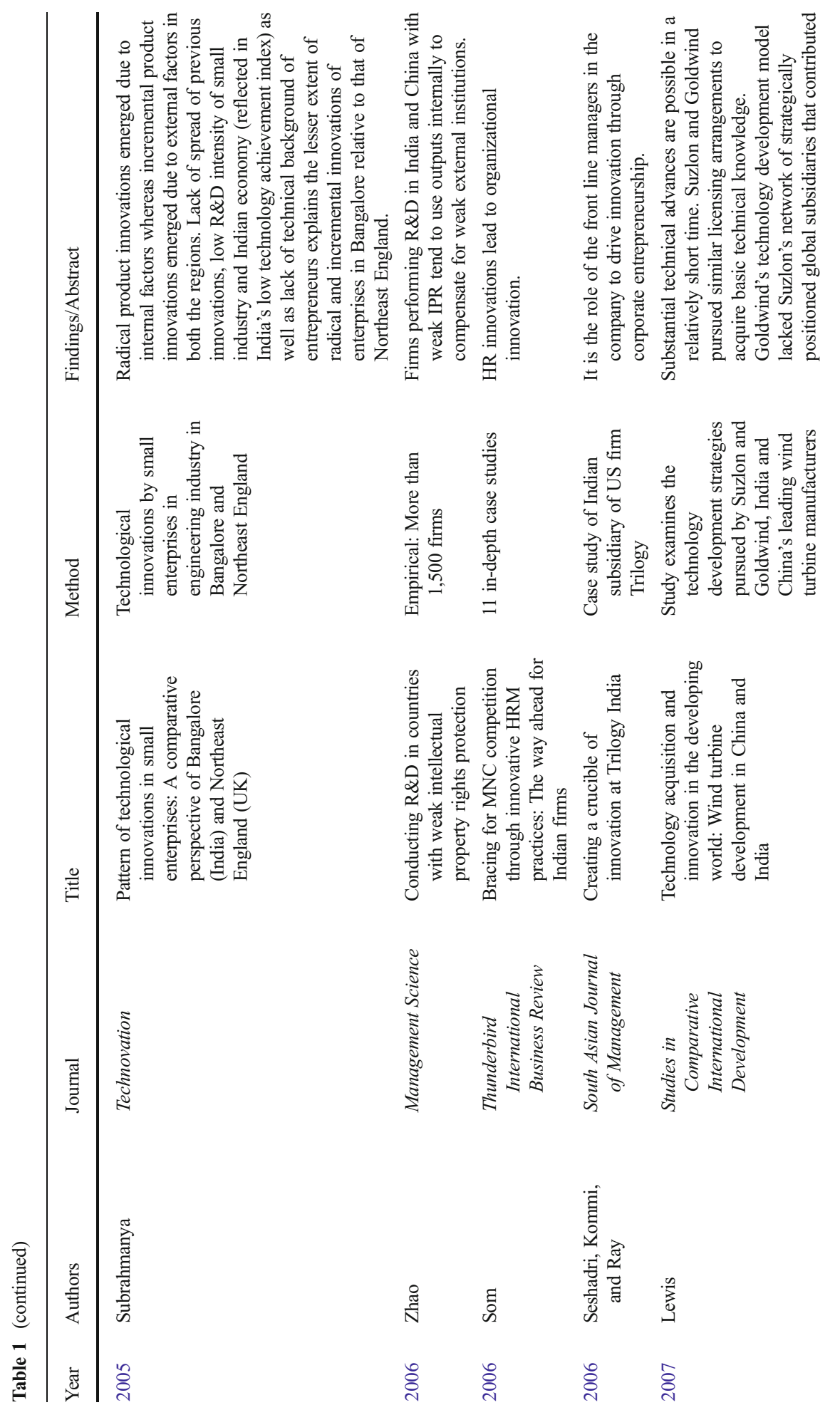




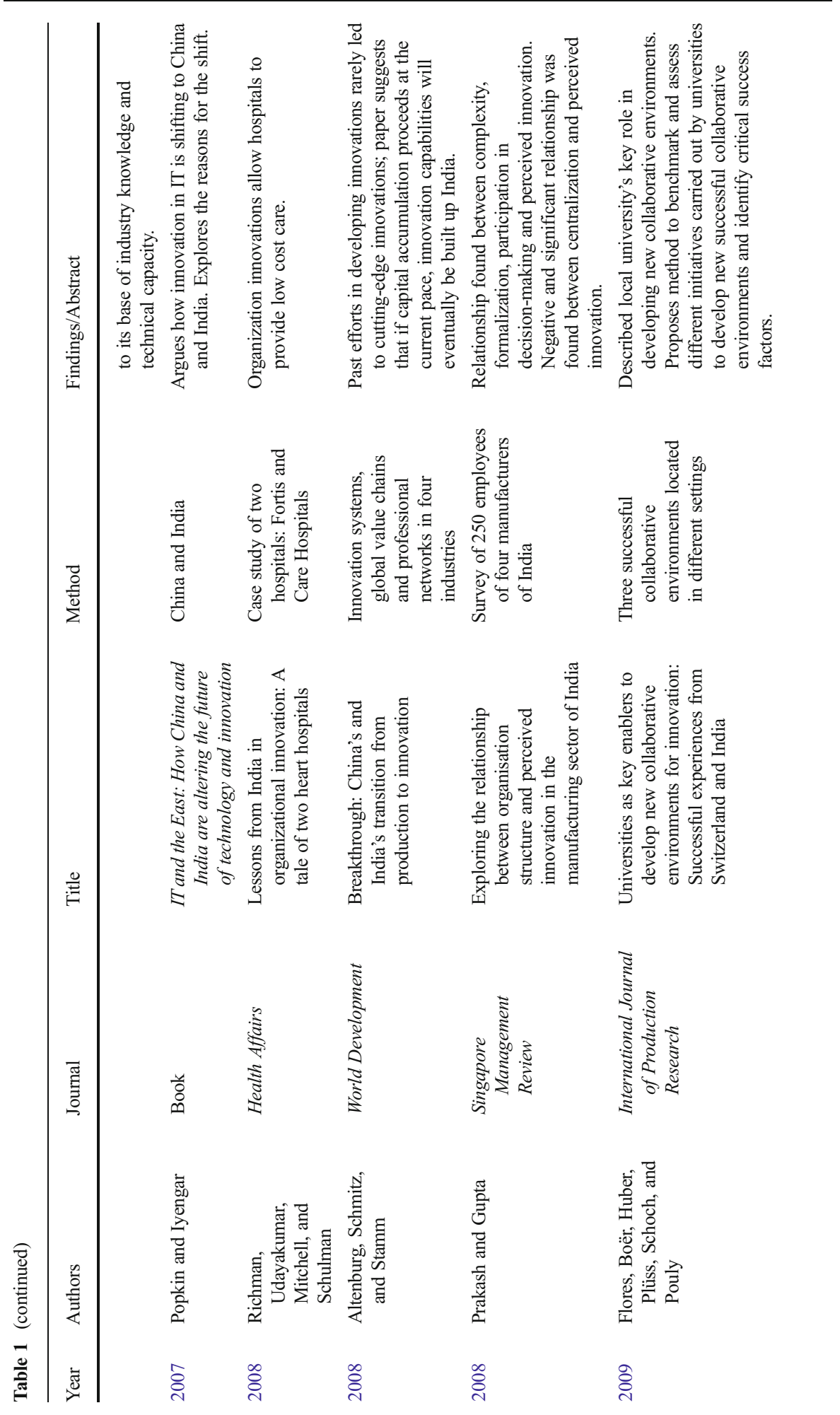




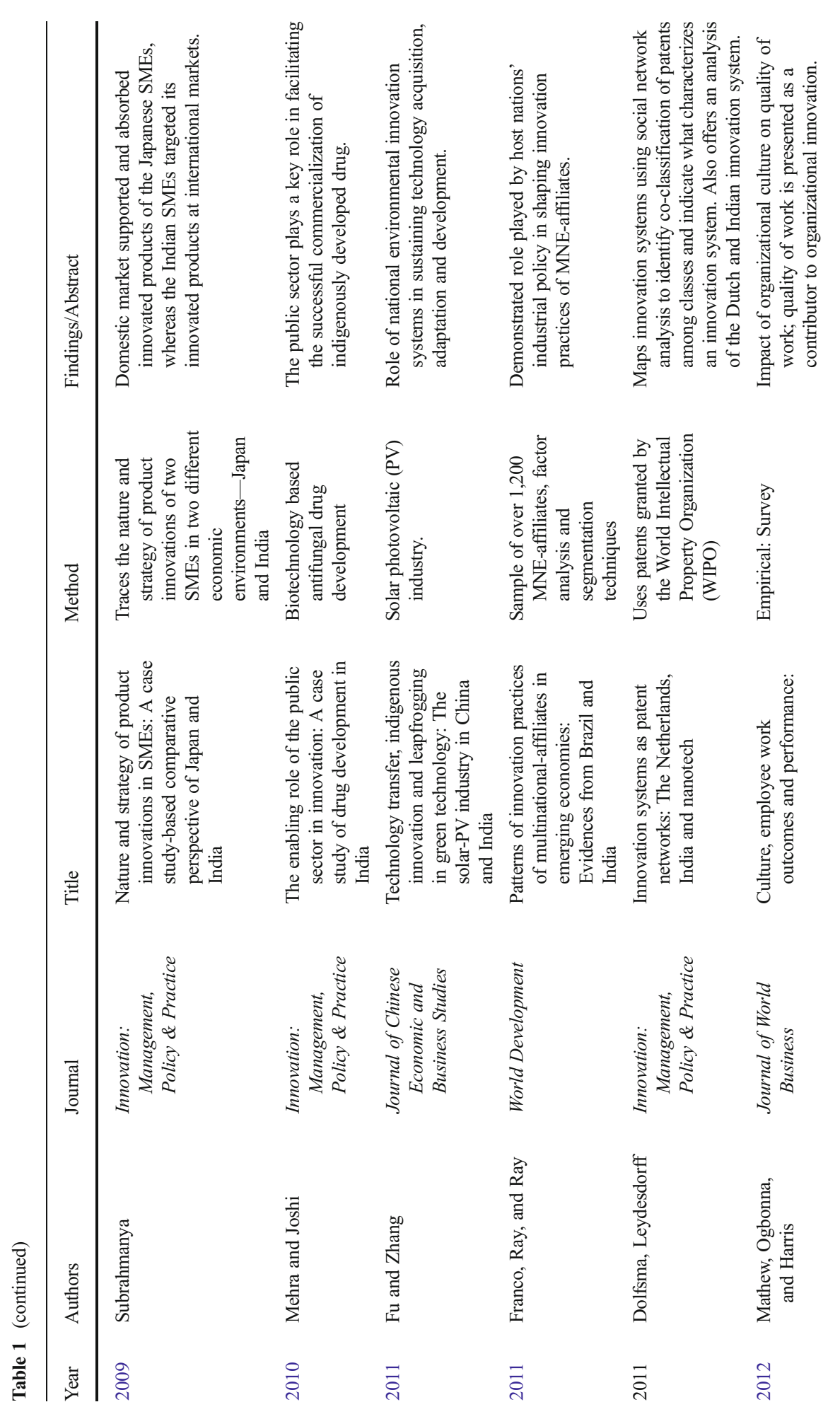




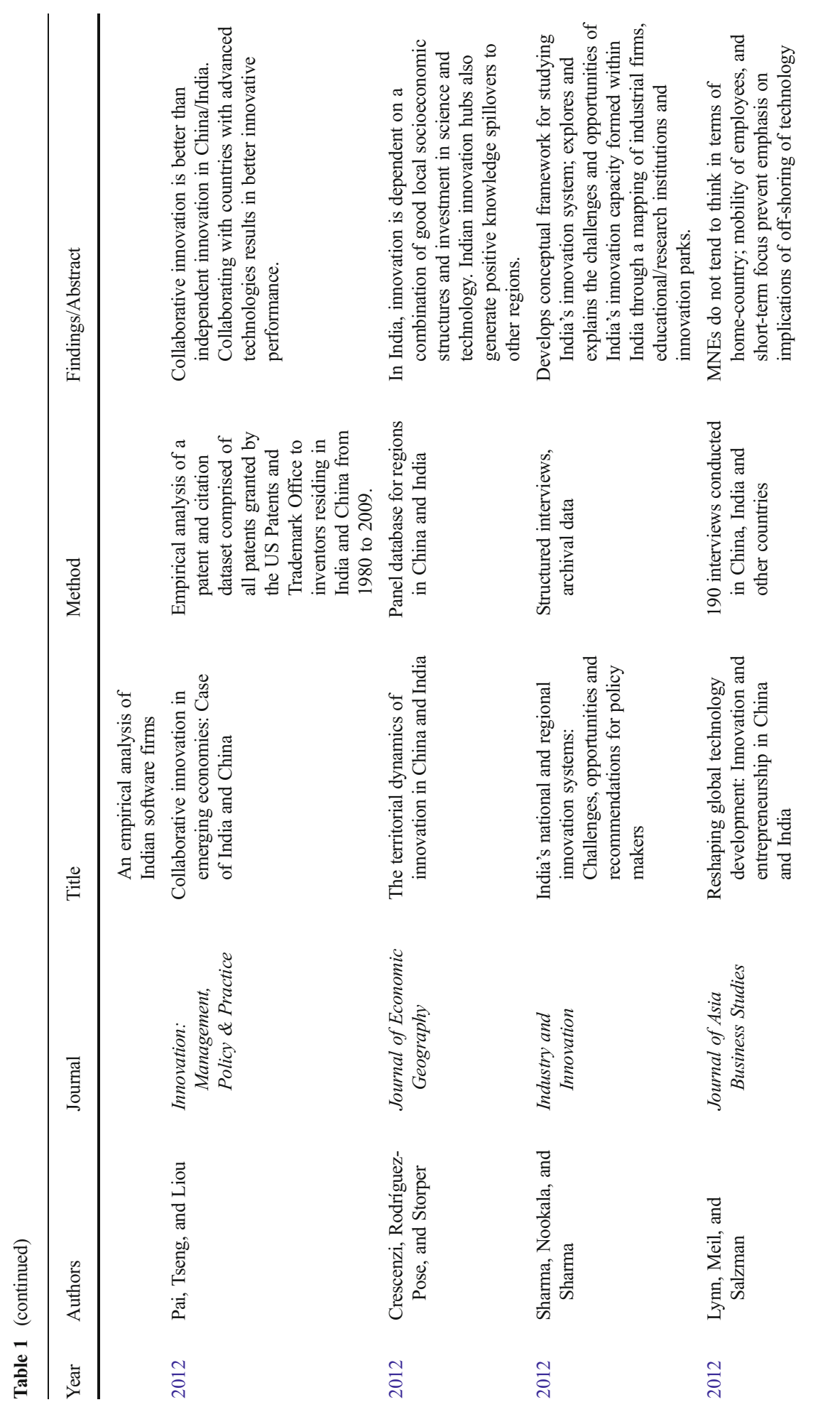




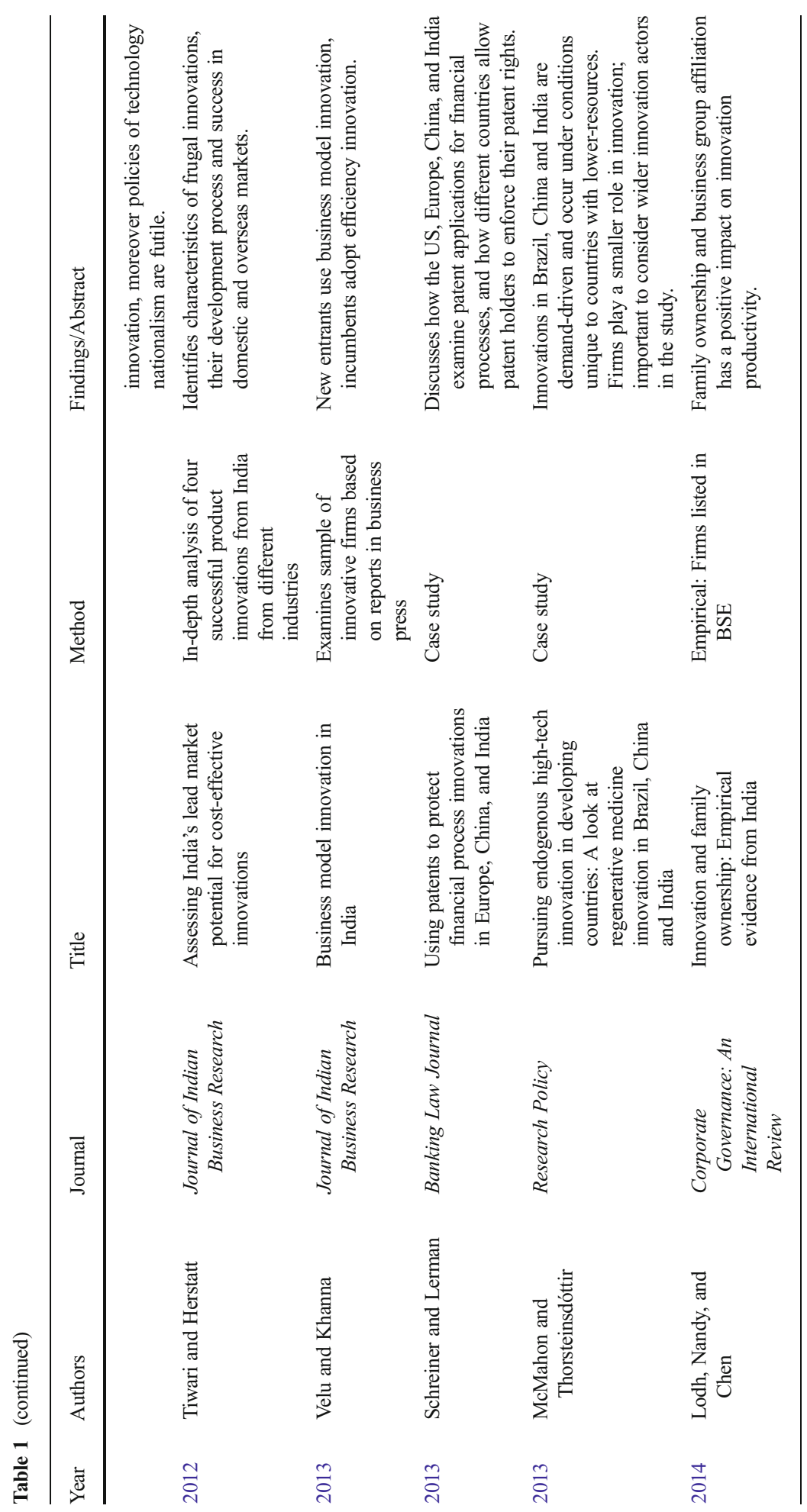


Table 2 Framework used in this study to classify existing research on Indian innovation

\begin{tabular}{ll}
\hline Level: Micro & Level: Macro
\end{tabular}

Focus: Outcome Impact of firm variables on innovation outcomes

Typical antecedents: Ownership, structure, strategy, HR systems/policies, business group membership, firm R\&D investment

Contingencies: Size, profitability, export markets

Focus: Product, service, and business innovations and patents

Theory: IO, contingency, RBV

Methodology: Positivistic, regression

Focus: Process Impact of firm variables on processes or impact of processes on outcomes

Typical antecedents: Employee skills, team/organization culture, HR policies, leadership, structure and strategy, resources and capabilities, inter-organizational linkages

Contingencies: Micro processes, motivations, learning, absorptive capability

Focus: Product, service, and business innovations and patents, ROI and micro processes involved in innovation: knowledge creation, learning \& retention

Theory: Learning/knowledge, RBV

Methodology: Descriptive/positivistic, cases, regressions
Impact of macro factors on innovation outcomes

Typical antecedents: Institutions and institutional changes: Liberalization, FDI, patent policies, industry structure, $R \& D$ tax policies

Contingencies: Ownership, industry, competition

Focus: Product, service, and business innovations and patents at firm, industry, and country levels

Theory: Institutional

Methodology: Positivistic, regression

Impact of macro factors on processes

Typical antecedents: Institutions and institutional changes, liberalization, FDI, patent policies, industry structure, R\&D tax policies

Contingencies: Firm factors, regional socio-political and economic systems

Focus: Agglomeration, spatial economics, linkages among institutions and knowledge flows, knowledge spillovers

Theory: Learning/knowledge, agglomeration

Methodology: Descriptive/positivistic, cases, regressions

patent policies have impacted innovation. For instance, Das (2004) found that after economic liberalization, while R\&D in certain segments of India's private sector increased, it decreased in the public sector; overall, R\&D spending among firms in most industries decreased, and innovation output suffered. According to this study, easy access to foreign technology likely reduced the need for in-house R\&D. Similarly, Kathuria (2008) examined the impact of FDI on R\&D investments by medium and high tech firms, and found that FDI flows have a negative impact (initially) on R\&D; economic reforms allowed such firms to import technology instead of investing in development and innovation.

Though Das (2004) found that overall R\&D spending has decreased, Dubey and Dubey (2010) noted that spending by R\&D centers set up as wholly owned subsidiaries (or partnerships) by MNEs in India has increased. For example, Singh (2006) noted that 
large firms such as IBM, AMD, Intel, Broadcom, and Cisco have set up chip design facilities in India. Confirming this trend, Chakrabarti and Bhaumik (2009) found that United States (US) MNEs have driven recent growth in patenting from India. However, as Asakawa and Som (2007) noted, increasing R\&D spending in India by MNEs did not necessarily mean that it was effective; instead they urge MNEs to be aware of the unique challenges posed by the institutional environment.

While MNEs have played a critical role in innovation during recent years, several studies have noted the role played by the Indian government in innovation in the past. Mahmood and Singh (2003), using US patent data, examined the role of foreign multinational, business groups, individuals, domestic firms, and research institutes on innovation over 30 years. They found that patent holding in India was relatively concentrated - the top 50 patent holders had a larger share of the patents than China. Furthermore, though there was a significant proportion of domestic firms and MNE subsidiaries in the top 50, the largest patent holder was Council for Scientific and Industrial Research (CSIR), a government owned organization. Consistent with this theme, Krishna (2007) discussed the critical role of public research organizations such as CSIR in innovations in India. He supported his thesis by describing CSIR's role in developing greener leather tanning technologies, and using tissue culture to reduce the time it takes for bamboo plants to flower.

While the above studies make clear that the government played a critical role in innovation policies prior to reforms, the impact of such policies on innovation remains unsettled. Some have suggested that the constraints and barriers to technology imports allowed the development of domestic R\&D and innovation, while others note that it was adversely impacted (e.g., Fan, 2011; Bhattacharya, 2011). Supporting the positive perspective, Guennif and Ramani (2012) noted that India's pharmaceutical industry's success in global markets (compared to Brazil's) can be attributed to government policies. Likewise, Kingston (2013) stated that Ireland's joining the international patent system in 1925 does not appear to have helped with innovation, whereas India's refusal to join may have helped with the development of its generic drug industry. In contrast, Sahoo and Shrimali (2013) in a study of the solar power industry, discussed how domestic content requirement in solar cell technology (favoring crystalline silicon cells and modules) adversely impacted innovativeness and competitiveness of the solar industry as developers preferred thin-film technology. Desai (1984) offered a more balanced perspective on the impact of government policies and explained how import substitution pressures led to the development of different types of domestic technology, which may have helped trigger the innovative capabilities of Indian firms. However, he acknowledged that there were many downsides as well, such as high cost, poor quality of capital equipment, and inability to import state-of-the-art technology.

Some studies have examined the impact of government policies on specific industries, with the pharmaceutical industry generating substantial attention in recent years. While in the past, the Indian pharmaceutical industry was largely content to reverse engineer products for domestic markets, Chaturvedi, Chataway, and Wield (2007) analyzed how changes prompted by public policy created new opportunities for pharmaceutical firms and made them research driven firms focusing on global markets. Within the broader liberalization theme, scholars have also examined the impact of specific changes, such as India's signing the Trade Related Intellectual Property Rights (TRIPS) patent law provision in 1994. Sampath (2006) conducted a survey of the 
Indian pharmaceutical industry to analyze the impact of patent rights on biomedical innovation. She found that patent protection in the biomedical sector had a negative impact on the number of projects pursued by firms under the TRIPS compliant regime.

We also found that studies that have conducted cross-country comparisons (e.g., Tseng, 2009) were particularly helpful in identifying India's unique innovation ecosystem. Tseng (2009) examined the technological innovation, innovation configurations, and strengths of BRIC countries. Based on an analysis of patents granted by the US Patent and Trademark office from 1976 to 2006, the study examined whether the innovations were incremental/radical, fundamental/applied; India scored higher on incremental innovation.

In contrast to the above studies that examined national institutions, several studies have focused on industry level factors and their impact on innovation. Desai (1985) examined how market structure was related to innovation generation and adoption by firms across 37 industries. The paper provides rich discussion of the complex factors that drive innovation. Similarly, Misra (2007) examined the impact of market structure on R\&D spending from 2000 to 2006 in more than 100 industries in the Indian manufacturing sector and found that there is an inverted U-shaped relationship between market concentration and industry innovativeness. He also found that the nature of the relationship was different for investment in product and process innovation and such investments were dependent on potential profit margins. Adopting a more focused approach, Prasad Mohanty and Augustin (2014) examined the evolution of one Indian firm, Mahindra \& Mahindra (M\&M), and how it has become innovative in response to challenges and opportunities in its industry. Specifically, the liberalization of automotive industry in the 1990 s encouraged M\&M to pursue internationalization by upgrading its technological capabilities and adopting an entrepreneurial growth model.

Overall, the macro-outcome based studies offer a rich area of work. As the above discussion suggests, scholars have examined how Indian regulations, patent laws, integration with the global economy, and national R\&D policies have impacted firms in several industries. Based on past research, we believe that it is fair to characterize the impact of the role of the Indian state on Indian innovation as mixed. While tariffs may have prevented Indian firms from being exposed to state-of-the-art technologies and innovation, it also shielded Indian firms from sophisticated foreign rivals and forced local firms to improvise. However, prior studies have failed to disentangle endogeneity and other mixed impacts of the governmental policies and interventions on innovation across various industries. Longitudinal cross-industry studies that incorporate the industry life-cycle into the analysis may be able to offer unique insights as to in what stage and what industries protectionist policies could encourage/hurt innovation. Due to the Indian state's deep involvement in many aspects of the Indian economy in the past, recent reforms and regulatory changes offer an attractive context to examine questions about innovation (cf. Jain \& Sharma, 2013, on the telephone industry in India).

In addition, India exhibits a substantial diversity in sub-national institutions, which may also result in heterogeneous innovation outcomes across regions (cf. Chan, Makino, \& Isobe, 2010; Gong, Chow, \& Ahlstrom, 2011). Unfortunately, studies looking into the array of formal and informal institutions within the Indian context, particularly in their role in innovation, are still few. Needless to say, the broader Indian innovation eco-system is in a state of flux and it is too early to discover any clear patterns on how it will shape innovation outcomes. Based on early studies, it appears 
that a very uniquely Indian eco-system is developing that involves MNEs, and professionally/family managed local firms that are tapping into the vast pool of Indian knowledge workers to develop innovations that serve the global elite and the local poor. In terms of theoretical background, institutional theory and industrial organization frameworks could offer the conceptual underpinnings for research in this stream. For instance, Schneider and Paunescu (2012) draw on the varieties of capitalism and national business systems literature to demonstrate how institutional configurations, as opposed to individual institutions, result in radical versus incremental innovation. A more holistic approach to institutions and industry conditions in the Indian context is likely to enhance our understanding of innovation outcomes in India as well. Increasing availability of data about patents (and other innovation metrics) make intra-national, regional, single industry, multi-industry studies, and cross-national comparisons feasible.

\section{Macro/process studies}

Studies in this group examine how national institutions influence innovation processes across firms and industries. One exemplar in this category would be Zhao's (2006) research, which found that weak intellectual property (IP) rights protection required MNEs to be careful about R\&D investment in India. According to Zhao's results, in such instances, MNEs may engage in R\&D that can be internally utilized, or develop alternative technology protection regimes that are internal. It is not just the weak IP protection, but also its lack of transparency that could pose hurdles to innovation (Acemoglu \& Robinson, 2012; Rodrik, Subramanian, \& Trebbi, 2004). Abraham and Moitra (2001) found, based on their analysis of patent applications in the field of Electric Communication Techniques in India and the US, that to make Indian patent data more useful for Indian firms, Indian industry needed access to detailed information on rivals' innovations. The recent changes in Indian patent laws have also attracted scholarly attention; Bowonder, Thomas, Rokkam, and Rokkam (2003) examined its impact on innovation processes at Dr. Reddy's laboratories (DRL) - they found how it led to DRL's focus on molecular discovery, which eventually led to DRL's expansion into international markets.

Some scholars have examined how institutional differences across countries explain differences in innovation processes among them. Chataway, Tait, and Wield (2007) investigated the research capabilities of pharmaceutical industry in developed countries, and then examined if Indian pharmaceutical industry's innovation model replicated the Western model or created an alternative model. They found that since liberalization, innovation in the Indian pharmaceutical industry is industry-led and imitative; however, it has not pursued risky and radical innovation, and lack linkages with governments, MNEs, and international funding agencies, which may prevent it from having a more significant impact on global markets. Similarly, in a comparative study, Franco, Ray, and Ray (2011) examined how host country industry policies (in Brazil and India) impacted knowledge and technology transfer into MNE affiliates. The study revealed how the MNE's innovation processes responded to their institutional environments. Specifically, in India, high tariffs to import of technology and government-funded research for certain areas resulted in a blend of practices among MNEs that involved 
development of internal competencies combined with linkages with partners to access complementary skill sets.

While the above group of studies focused on the impact of macro factors on firm processes, another group of studies has focused on the impact of such factors on industry and regional innovation processes. Research in spatial economics and regional agglomeration has examined how market and regional policies interact to create regional innovation systems (for example, software firms in Bangalore) and how they influence innovation (Chaminade \& Vang, 2008). Chaminade (2011) compared the geography of linkages of the automotive and software industries in (Pune) India and (Greater Beijing) China. Using surveys and interviews, she identified how the networks among customers, suppliers, and MNEs are different in the two regions and across industries and how they impact innovation. Results revealed that there was a significant difference between Pune and Greater Beijing with regard to both the organization and the geography of the networks. Firms in Pune depended more heavily on local-global relationships while those in Beijing were more concentrated in domestic markets.

Similarly, Crescenzi, Rodríguez-Pose, and Storper (2012) used patent data to compare and contrast the spatial patterning of innovation systems across China and India. In contrast to China, they argued that in India, such clusters generated positive knowledge spillovers. They relate the landscape of innovation in India to "specific socioeconomic and institutional conditions of Indian states, such as the differences in social filter, networks, policies and practices" (Crescenzi et al., 2012: 1078).

Within this stream, one group of studies has examined linkages among firms, customers, universities, and developmental organizations. For instance, Roy and Banerjee (2011) identified the differences across Indian cities in terms of the interaction between university, government labs, and industry in bio-medical research. Several scholars working in this stream have noted the weak linkages that exist between the technology generators (universities and R\&D laboratories) and technology users (especially the smaller organizations and their lack of motivation to upgrade capabilities) (Sikka, 1999). Joseph and Abraham (2009) examined the factors that increase the industry-academia linkages and the outcomes of such linkages, specifically finding that in the Indian context firm-academia interaction led to innovativeness. Similarly, Chandra and Krishna (2010) examined the linkages of the five Indian Institutes of Technology (IITs) with industries and analyzed the interfaces and knowledge transfer process. Providing an example of a successful collaboration, Samii, Van Wassenhove, and Bhattacharya (2002) discussed how the UN Industrial Development Organization (UNIDO) linked up with other organizations to upgrade the capabilities of automotive component suppliers in India to enable them to supply world class manufactures. Relatedly, Reece (2007) examined how an Indian firm bred a salt-tolerant form of hybrid rice through linkages with national and international institutions. Some guidance on how these networks could be developed is offered by Sharma, Nookala, and Sharma (2012) who used a survey of managers to examine India's opportunities and challenges in cooperation between industry, education intuitions, and government labs. The need to establish a more vigorous link between industry, academia, and the government R\&D labs appears to be a common theme (Chandra \& Krishna, 2010; Chidambaram, 2011) among many of the macro process studies.

A few studies have examined the role of the national culture and informal institutions on innovation processes. Russell (2008) noted that while innovation 
remains a critical priority for Indian industry's competitiveness, cultural factors, hierarchical structure, and testing practices deterred innovative performance. Though not explicitly focusing on cultural analysis, Liu, Kaza, Zhang, and Chen (2011), using network analysis, described the important role of status in social networks on diffusion of knowledge and innovation in the nano-technology literature in China, Russia, and India. Likewise, Khandwalla (2014), one of India's leading writers on creativity and innovation, developed a model that integrated the role of government, educational institutions, and civil society in generating innovation. As studies in this category illustrate, innovations comprise various micro processes, including learning and knowledge flows. Thus, unraveling the links between the macro structure (institutional and industrial) and their impact on micro processes will be critical to understanding how innovation occurs in the Indian context.

Overall, studies in this category suggest that over the years, India's policies and societal structure have created a very unique eco-system that drives the innovation processes within and across firms, industries and regions. While the policies are undergoing rapid changes, it is not clear whether the past processes have changed uniformly across sectors or new processes have been fully established. In our view, innovation efforts may be constrained by processes that were established over the years when state control and regulations were more intrusive-processes tend to be inertial and sticky, hence the challenge for innovators would be to identify ways to prune and modify them. Additionally, we still lack a proper understanding of how and why the innovation process differs across industries in India. The unique features of the Indian eco-system and industries provide fertile grounds to pry open the black box of the innovation process in India by bringing in theories of industry recipes, mental models, and imprinting. Recent changes in India's institutional and competitive environments offer opportunities for scholars to examine how such changes are impacting or disrupting innovation processes within and across firms.

\section{Micro/outcome studies}

Studies in this category examine firm level factors and how they influence innovation outcomes. Within this group we include studies that have examined the impact of firm ownership, R\&D, HR policies, structure, and strategy on innovation. For example, Lodh, Nandy, and Chen (2014) found that family ownership and business group affiliation have a positive impact on innovation in India. Some studies have specifically examined the link between R\&D investment and innovation. For example, Dubey and Dubey (2010) found that despite increased R\&D spending, Indian pharmaceutical firms have not seen a substantial increase in their drug pipeline and approval of new molecular entity (NME) rate, though there has been an increase in incremental innovations and applications for new drug approvals.

Some studies in this group also looked at the moderating factors that influence the link between R\&D and innovation outcomes. Mishra (2010) pointed out that the changes in Indian patent law in 2005 had led to an increase in R\&D investment; however, the investment was not uniform across firms, and has not led to a proportionate increase in innovations. He found that more than half of the Indian pharmaceutical firms did not engage in R\&D spending, and that such spending was a function of the past profitability, size, capital intensity, and exports. Highlighting the role of 
appropriate skills-sets for innovation, Deolalikar and Roller (1989) found that patenting by Indian firms was related to the availability of human capital rather than R\&D investment, capital, or organization size. Findings regarding the effectiveness of R\&D spending on innovation appear to be mixed, and more studies are needed to understand the contingency factors that influence the relationship.

Because of India's strengths in service exports, several studies have looked at service innovations. Thakur and Hale (2013) compared factors influencing service innovation in the US and India and their impact on firm performance. The study tested its hypotheses using a survey instrument in the financial, medical, food, hospitality, and communication services. They found that there were some differences in factors driving service innovation in India and the US; in India, it was the competitive environment that was more strongly associated with service innovation, whereas in the US, it was demanding customers. However, in both countries innovation was associated with superior performance.

While a majority of studies have examined product/service innovations, Velu and Khanna (2013) focused on business model innovation. They identified 95 business model innovations reported in popular business media and examined each one in detail to identify its characteristics. They found that business model innovations tend to be made by new firms, whereas existing firms adopt efficiency innovation. Examples of business model innovation included pharmaceutical firms that do contract research for Western pharmaceutical firms - a topic that has also been examined by Awate, Larsen, and Mudambi (2015) and Haakonsson, Jensen, and Mudambi (2013). Such business model innovations were not just limited to pharmaceutical and IT, but were also occurring in consumer goods and other areas.

Surprisingly, this group of research was underrepresented in our review. While scholars have examined the impact of ownership and R\&D spending on innovation outcomes, there are several other firm level factors that could have potentially been examined as determinants of firm innovation. Corporate governance practices, managerial capabilities, business and corporate strategy, and organizational change capacity and routines are all areas which remain unexplored in the context of innovation in India. Here, rich theoretical frameworks such as the resource-based view or dynamic capabilities view could offer strong theoretical framing for additional inquiry. Such theoretical framing would allow scholars to not only examine the impact of firm factors on innovation, but also how they interact to influence outcomes. Also, due to government's involvement in many sectors of Indian economy, examining the firms' capabilities and resources such as political ties or network attributes could help disentangle the mixed results.

Given the changes occurring in the Indian corporate landscape, scholars have significant opportunities to engage in this area of research. We highlight some of this potential in the section on future research.

\section{Micro/process studies}

This group of studies examined intra-firm processes that are related to innovation. Broadly, these studies focus on the "how" of innovation. Among one of the earlier studies in this group, Chaudhuri (1986) examined the managerial processes involved in a major technological innovation and found that the following factors were critical: 
presence of product champions and upper leadership support, effective relationship between leaders and key decision makers in government, close association among innovation team members, and connection between the technology development and manufacturing enterprise.

The role of the individual and the individual's interaction with the organizational eco-system in the innovation process was examined by Waychal, Mohanty, and Verma (2011) in an empirical study within an IT company. They found that employee selfconfidence and a culture of celebrating success were related to innovative thinking and value creation. Organizational culture's impact on innovation has also been examined by others (e.g., Dixit \& Nanda, 2011); Mathew, Ogbonna, and Harris (2012) found that organizational culture impacts quality of work, which in turn impacts innovation. Bhatnagar (2014) examined the role of perceived supervisor support, reward, and recognition on employee innovative behaviors. She found that recognition and rewards mediated the relationship between perceived supervisor support and innovation. Drilling down further into a more micro level, Bhaduri and Kumar's (2011) study focused on the role of extrinsic and intrinsic motivators in innovation activities and concluded that innovation was driven by intrinsic factors.

Taking a broader structural view, Krishnaswamy and Kamala (1979) discussed how investment in R\&D could be more effective when the function was linked to marketing and production. In contrast, adopting a more strategic approach, Bettiol, Di Maria, and Grandinetti (2012) examined the competing pressures of standardization and creativity to generate innovation in knowledge intensive business services firms (KIBS) in India and Italy. Similarly, Krishnan (2012) examined the innovation strategies (e.g., exploration versus exploitation, market-pull versus technology push, internal versus external development of capabilities, and product versus process focus) within leading Indian firms. He found that leading firms use business model innovations to enhance affordability of their products and services, and use technology as a means to deliver such innovation. Such firms differed in their innovation process from other firms in that they were ambidextrous on all four innovation dimensions identified above. Plechero and Chaminade (2013) examined how firms in three industries (auto component, software, and green biotech) have globalized their innovation. They included three distinct modes (or processes) of globalization of innovation in their study: exploitation of innovation, sourcing of technology, and research collaboration.

Some studies have focused on firm level resources and capabilities required for innovation. Kale (2010) examined the learning processes involved in the development of R\&D capabilities that support innovation. He examined inter-firm variation in such capabilities and how they were created. Many firms lacked innovation capabilities, and after economic reforms, such firms sought to acquire them through internationalization and acquisitions (Chittoor, Sarkar, Ray, \& Aulakh, 2009). Focusing on acquisition integration process and innovation, Sen and Rubenstein (1989) examined the role of $R \& D$ in acquisition integration and found that involving in-house R\&D groups in both the acquisition and implementation phases of the external technology process was very beneficial in improving the efficiency of the process.

Several studies have approached innovation processes from a knowledge creation and management perspective. Birasnav and Rangnekar (2010) surveyed employees in Indian manufacturing firms to identify knowledge management processes and how these processes were linked to innovation culture. Veng Søberg (2011), employing 
knowledge creation theory and a case study approach, identified factors that prevent knowledge creation within Scandinavian R\&D centers in China and India, and skill sets involved in process innovation. He found that while weak socialization skills may impede effective knowledge transfer and consequently hurt the innovation process in foreign invested R\&D units, it was codification skills that spurred innovation in India. Likewise, Roy and Gupta (2007) examined product development in a small foundry in India and analyzed how the processes depart from Nonaka and Takeuchis' socialization-externalization-combination-internalization (SECI, 1995) model. The authors discussed how the case study setting supported as well as departed from each element of the model, thus helping reveal the uniquely Indian way of knowledge creation.

Another group of studies look at the influence of inter-organizational linkages on innovation processes. For example, Kumar and Subrahmanya (2010) examined how small and medium enterprises (SMEs) partner with MNEs in the auto industry and found that SMEs mostly received product related and purchase process assistance with little assistance for their production, marketing, human resource, financial, and organizational requirements. Yet even such assistance was critical in enhancing these SMEs' innovativeness and performance. Rai, Pedersen, and Kazakevičiūtė (2010) used three case studies to understand the co-creation of innovations in India's ICT industry. They found that much of the co-creation was focused on the domestic market; co-creations occurred through joint ventures rather than alliances, and it led to sharing of knowledge. According to Maini (2005), the development of India's first electric car company REVA occurred through knowledge sharing within a joint venture between Maini Group and AEV LLC of California.

Taking a broader approach, Karna, Täube, and Sonderegger (2013) examined characteristics of MNE subsidiaries embedded in networks within geographic clusters (such as Bangalore) and their impact on innovation through knowledge flows. Likewise, Pai, Tseng, and Liou (2012) offered a solution to the problem of low effectiveness of R\&D spending; examining patent data, they found that in India, collaboration with participants from advanced countries on innovations were more effective than independent work.

While many studies above examined linkages among Indian firms and MNEs or government institutions, some have examined linkages among firms and customers. Subrahmanya (2007), for example, examined how Indian SMEs in the Bangalore area have responded to customer demands that resulted in innovation and have even allowed two of the foundries to enter international markets. In another study, Kim, Basu, Naidu, and Cavusgil (2011) examined the innovativeness of born global firms and how their customer orientation leads to innovativeness - the relationship being mediated by their technological expertise. Alam (2012) investigated how local firms and MNEs differ in business to business new service development processes. Interestingly, he found that MNEs tend to target new markets with new services, whereas Indian firms tended to focus on moderately innovative services. He also found that MNEs had a more rigorous idea generation process than the indigenous firms. Another paper on service innovation (Alam, 2013) used a longitudinal study to examine the development process of new service projects in real time and found that firms used different approaches such as customer advisory panel and innovation retreats to generate new services. 
This stream of research on organization processes associated with innovation has identified one uniquely Indian approach to innovation-jugaad. Jugaad is a word in the Hindi language, which is spoken in much of northern India. It means improvisation under resource constraints, which speaks to the heart of the "frugal" nature of Indian innovation and pragmatically minimizing the use of resources across the value chain in order to reduce offering cost, while maintaining an acceptable quality standard (Jain, 2012; Prabhu \& Jain, 2015; Prahalad \& Mashelkar, 2010). Tiwari and Herstatt (2012) examined characteristics of frugal innovation, its development process and success in domestic and overseas markets. Their work offers MNEs insights into developing frugal innovations and asserts that such innovation need not be national, but could be part of global innovation networks. However, more research is needed to explain how Indian MNEs can integrate the innovation initiatives across their global networks and how they can translate their experiences overseas into local innovations.

Overall, the research on innovation processes, factors that influence them, and how they differ across firms, appear to be fairly rich with the most interesting ones focusing on processes that are uniquely Indian. More studies that identify processes like jugaad, and compare them to organizational processes in other contexts, would help enrich the broader literature on Indian innovation. In essence, while what we know about the different innovation processes Indian firms develop, and the unique organizational characteristics driving these differences, is impressive, many open questions remain. For instance, given the dynamic nature of Indian economy, it is surprising that few studies discuss organizational imprinting and the evolution of innovation processes over time within Indian organizations.

In terms of methodology, unlike the previous group of studies that used archival data, studies in this group tend to use surveys or detailed case studies. For instance, a comprehensive case study of Ranbaxy Pharmaceuticals by Bowonder and Mastakar (2005) illustrated how leadership, strategies (e.g., joint ventures), and market focus together led to innovation and growth. These studies are rich in detail, though it would be helpful for studies in this group to validate their findings with archival sources and more rigorous methods. In any case, process based studies have the potential to uncover uniquely Indian issues that enable or constrain innovation.

\section{Discussion}

In recent years, scholars, practitioners, and policy makers alike have argued that innovation by Indian firms will play a critical role in India's economic vitality and growth. The purpose of this paper was to contribute to this discussion by reviewing extant studies on innovation in India to not only take stock of the research but identify its contours, uniqueness, and develop some implications and guidance for future research.

We were encouraged by the richness of Indian innovation research. While its impact has not been pervasive in top management journals, high quality work has been done in management and allied fields by a large group of scholars, some of whom have dedicated years or even decades to this research stream. As must be evident from the above review, scholars have adopted several different perspectives and theories to frame research on Indian innovation, including institutional, industrial organization, 
social network, resource/knowledge-based view, cultural, governance, and structural theories. Studies on innovation have included large samples as well as detailed case studies within firms and sometimes across firms within an industry. While it is difficult to say that an overarching, simple and generalizable theme can capture the state of Indian research, our review finds that the Indian innovation eco-system is distinctive, rapidly undergoing changes, and thus offers exciting opportunities for future research.

\section{Future research directions}

Our review suggests that there are many unanswered questions in the Indian context for innovation research. As Fig. 2 suggests, the number of approved patent filings from India continues to be low. Researchers could examine the macro and micro factors and processes that positively or negatively impact the ability of firms to translate innovation processes and applications to actual commercially-viable innovation in the Indian context. At the macro level, scholars could further explore how institutions impact innovation. For example, how do Indian university and secondary school curricula impact the development of research capabilities and innovation? It is clear that the Indian Institutes of Technology (IITs) and many other well- respected scientific and engineering institutes in India have the potential to play a much larger role in generating innovation. Policy makers could examine how incentive systems in such institutes influence faculty involvement in research and enhance linkages with industry. Further, scholars and policy makers could examine the level and effectiveness of funding to support research and innovation processes. For example, in the US, National Science Foundation (and other federal and state governments organizations such as Department of Energy, Department of Science) have established an extensive framework to solicit, evaluate, and fund research projects at universities. In addition, private foundations and funds complement such government-funded projects.

Beyond formal institutions, scholars could examine how informal institutions facilitate or hinder innovation (Acemoglu \& Robinson, 2012; Parente \& Prescott, 2002; Wang, Ahlstrom, Nair, \& Hang, 2008). For example, Tansuhaj, Gentry, John, Lee Manzer, and Jin Cho (1991) examined how cultural values of fatalism, traditionalism, and religious commitment were related to the willingness to try new products. Similar studies that incorporate such institutions could help develop a uniquely Indian perspective on innovation. For instance, what is the role of culture in interpreting and valuing innovations and their impact? How does India's unique socio-cultural environment influence knowledge flows and risk taking attributes and impact innovation and diffusion process? Such institution based studies could uncover how India's national business system is configured in relation to other varieties of capitalism (Judge, Fainshmidt, \& Brown, 2014), and what these institutional differences entail for innovative output. As discussed earlier, a more nuanced approach focusing on sub-national institutional differences and their influence on innovation output and process is warranted as well.

At the micro-level, a fascinating area of work could be to follow Koppman and Gupta (2014) and examine how distributed work - where scientists and engineers work on different parts of projects in different geographic locations - combines knowledge and creates innovations. As Khavul, Peterson, Mullens, and Rasheed (2010) argue, globalization of innovation by emerging market firms may require development of new 
capabilities. In this context, scholars could examine how effective foreign companies (and Indian MNEs) are in managing innovation across subsidiaries. How do ownership structure (e.g., business group, family, state), governance, firm size, and firm age independently and in interaction influence innovation? What are the uniquely Indian organizational problems (and solutions) in managing innovation? For instance, Duran, Kammerlander, van Essen, and Zellweger (2015) showed that family firms tend to invest less in $\mathrm{R} \& \mathrm{D}$, but are more innovative on average due to a unique process of translating research investment into innovative output. How does this process work in Indian family, state-owned, or foreign-affiliated firms? Much work remains to be done in order to pry open the black box of the Indian innovation process.

In addition, more work is needed that examines administrative innovations, as well as the reasons for Indian firms' preference for incremental instead of radical innovation, innovation commercialization, and product development. In addition to studies that examine the antecedents of innovation at a firm level, we also need studies that examine the impact of innovation on firm performance, customers (Tarafdar, Singh, \& Anekal, 2013) and corporate governance (Ravishankar, 2013). ${ }^{6}$ At the industry, regional, or national level, scholars could use established theoretical frameworks such as the Diamond Model (Porter, 1990) to understand Indian innovation type, volume, and productivity. Finally, it is still unclear how Indian firms' internationalization affects their innovation process and outcomes, which future research could endeavor to uncover.

\section{Limitations}

Any study that attempts to review a broad topic such as innovation is constrained to limit its scope due to journal page limit guidelines. While our focus in this review was primarily on the antecedents of innovation, a vital area of research on innovation, which we excluded from this review, examines the consequences of innovation. Both macro and micro studies have examined the performance implication of innovation (Manimala, Jose, \& Thomas, 2006). For instance, Hsu (2009) found that patent stocks were positively associated with market returns and premiums. Similarly, Chadha (2009) found that foreign patent rights of Indian pharmaceutical firms were positively associated with export performance. However, we also find cases (e.g., Amitabh's [2013] study of the glass industry) where increasing competition was causing some firms to focus more on efficiency and productivity improvement rather than innovation. Clearly, there is need for more studies in this area.

Another significant omission in this paper was the review of research on agricultural innovation. Unlike Dong and Saha (1998), we do not examine technology adoption or diffusion rate of innovation in the unorganized, agricultural sector (Raina, 2003). Das (2011) pointed to the need to integrate rural SMEs into the formal sector, the financial markets, and global markets; such integration would also unleash innovation and productivity. Relatedly, we also did not examine innovations in social entrepreneurship (Bhatt \& Altinay, 2013). We believe these are areas that deserve more research.

\footnotetext{
${ }^{6}$ Messner (2011) pointed out the role of governance in tapping into the potential gains from innovation in offshoring activities (in addition to factor cost savings).
} 
While we noted the omissions, we must also acknowledge that sometimes we included papers in our review that may have fallen outside the boundaries we defined if they helped us understand the uniquely Indian innovation process. For instance, we included papers in our review that were not strictly about innovation processes or outcomes, but focused on R\&D spending. While R\&D investment is not equivalent to innovation, we found that including papers that focused on R\&D did help us assess the Indian innovation landscape.

\section{Conclusion}

With its large number of renowned universities and research institutions, India has the potential to become a global hub of (growth-encouraging) innovation. However, the lack of successful patent filings from India suggests that there are several hurdles that must be overcome for India to become an innovation superpower. First, our review shows that India suffers from a lack of innovation infrastructure. As Mathew (2011) notes, while many have iPhones, a vast section of India's populace lacks access to necessities that are taken for granted in more developed countries. In order to fully maximize its innovative potential, India needs to develop its legal, physical, scientific, technological, and medical infrastructures. Thus, more research is needed not only on the outcomes associated with infrastructure investment, but also on how such investment results in innovation. The role of MNEs entering India in filling these institutional voids is another fruitful research avenue. In addition to development of such infrastructure, policy makers need to examine how to strengthen the linkages among the different institutions (Acemoglu \& Robinson, 2012).

Second, India needs to develop its eco-system to support entrepreneurship. In our view, innovation and entrepreneurship go hand in hand; fostering entrepreneurship requires a focus on the channels to fund new business ideas, such as angel investors and venture capitalists (Alvarez et al., 2015; Bruton, Ahlstrom, \& Singh, 2002; Lerner, 2009). Relying on banks alone to support new start-ups will not be enough, as such institutions are more geared to fund large ongoing enterprises and may be more risk averse. Prior studies have proved the significant role of venture capital (VC) industry in fostering entrepreneurship and innovation in the West (Florida \& Kenney, 1988) and in Asia (Bruton, Ahlstrom, \& Yeh, 2004). Here, research looking into factors attracting international VC funds, and the effective ways in which a VC industry can flourish within India is warranted (cf. Bruton et al., 2002).

Finally, and perhaps most importantly, in order to realize the enormous innovative potential of the Indian population, rural areas must be developed by introducing policies that advance education, health, and wealth creation. Furthermore, the emerging literature on Indian innovation suggests that innovation needs to address the widespread poverty in the country and be appropriate to the context; thus, we believe that the title of a paper by Kaplinsky (2011) "Schumacher meets Schumpeter" regarding lower-end technological innovation, captures India's innovation needs perfectly. We hope that this paper brings to light the need for more concerted and collective scholarly efforts (Abrahamson, 2008) to study innovation and supporting prescriptive measures to further encourage innovation in India (Acemoglu, 2003). 
Acknowledgment The authors thank Sanjay Jain for his extensive comments on an earlier version of this paper. The authors also thank Marc Ahlstrom of Rowan College at Burlington County for his editorial assistance.

\section{References}

Abraham, B. P., \& Moitra, S. D. 2001. Innovation assessment through patent analysis. Technovation, 21: 245252.

Abrahamson, E. 2008. 22 things I hate: Mini rants on management research. Journal of Management Inquiry, 17(4): 422-425.

Acemoglu, D. 2003. Root causes: A historical approach to assessing the role of institutions in economic development. Finance \& Development, 40(2): 27-30.

Acemoglu, D., \& Robinson, J. 2012. Why nations fail: The origins of power, prosperity, and poverty. New York: Crown Business.

Adner, R. 2006. Match your innovation strategy to your innovation ecosystem. Harvard Business Review, 84: 98-107.

Aghion, P., \& Howitt, P. 1992. A model of growth through creative destruction. Econometrica, 60(2): 323351.

Aghion, P., \& Howitt, P. 1998. Capital accumulation and innovation as complementary factors in long-run growth. Journal of Economic Growth, 3: 111-130.

Ahlstrom, D. 2010a. Innovation and growth: How business contributes to society. Academy of Management Perspectives, 24(3): 10-23.

Ahlstrom, D. 2010b. Publishing in the Asia Pacific Journal of Management. Asia Pacific Journal of Management, 27(1): 1-8.

Ahlstrom, D. 2014. The hidden reason the First World War matters today: The development and spread of modern management. Brown Journal of World Affairs, 21(1): 201-218.

Ahlstrom, D., Young, M. N., \& Nair, A. 2003. Navigating China's feudal governance structures: Some guidelines for foreign enterprises. SAM Advanced Management Journal, 68(3): 4-13.

Ahlstrom, D., Lamond, D., \& Ding, Z. 2009. Reexamining some management lessons from military history. Asia Pacific Journal of Management, 26(4): 617-642.

Alam, I. 2012. New service development in India's business-to-business financial services sector. Journal of Business \& Industrial Marketing, 27(3): 228-241.

Alam, I. 2013. Customer interaction in service innovation: Evidence from India. International Journal of Emerging Markets, 8: 41-64.

Altenburg, T., Schmitz, H., \& Stamm, A. 2008. Breakthrough? China's and India's transition from production to innovation. World Development, 36: 325-344.

Alvarez, S. A., Barney, J. B., \& Newman, A. M. 2015. The poverty problem and the industrialization solution. Asia Pacific Journal of Management, 32(1): 23-37.

Amitabh, M. 2013. The entrepreneur's dilemma: Case of TMT toughened glass pvt. Ltd. Asian Case Research Journal, 17: 225-241.

Anand, R., \& Anand, U. 2009. Inventive Indians. New Delhi: Nimby Books.

Arora, A., Drev, M., \& Forman, C. 2009. Economic and business dimensions: The extent of globalization of software innovation. Communications of the ACM, 52: 20-22.

Asakawa, K., \& Som, A. 2007. Internationalization of R\&D in China and India: Conventional wisdom versus reality. Asia Pacific Journal of Management, 25(3): 375-394.

Awate, S., Larsen, M. M., \& Mudambi, R. 2015. Accessing vs sourcing knowledge: A comparative study of R\&D internationalization between emerging and advanced economy firms. Journal of International Business Studies, 46(1): 63-86.

Bajpai, N. 2002. A decade of economic reforms in India: The unfinished agenda. CID working paper no. 89, Center for International Development, Harvard University.

Baregheh, A., Rowley, J., \& Sambrook, S. 2009. Towards a multidisciplinary definition of innovation. Management Decision, 47: 1323-1339.

Basu, K. 2004. India's emerging economy: Performance and prospects in the 1990s and beyond: 3-26. Cambridge: MIT Press.

Bettiol, M., Di Maria, E., \& Grandinetti, R. 2012. Codification and creativity: Knowledge management strategies in KIBS. Journal of Knowledge Management, 16: 550-562. 
Bhaduri, S., \& Kumar, H. 2011. Extrinsic and intrinsic motivations to innovate: Tracing the motivation of 'grassroot' innovators in India. Mind \& Society, 10: 27-55.

Bhatnagar, J. 2014. Mediator analysis in the management of innovation in Indian knowledge workers: The role of perceived supervisor support, psychological contract, reward and recognition and turnover intention. International Journal of Human Resource Management, 25: 1395-1416.

Bhatt, P., \& Altinay, L. 2013. How social capital is leveraged in social innovations under resource constraints?. Management Decision, 51: 1772-1792.

Bhattacharya, S. 2011. Innovation in India: A path to knowledge economy. Journal of the Knowledge Economy, 2: 419-431.

Birasnav, M., \& Rangnekar, S. 2010. Knowledge management structure and human capital development in Indian manufacturing industries. Business Process Management Journal, 16: 57-75.

Bowonder, B., \& Mastakar, N. 2005. Strategic business leadership through innovation and globalisation: A case study of Ranbaxy Limited. International Journal of Technology Management, 32: 176-198.

Bowonder, B., Thomas, M. T., Rokkam, V. M., \& Rokkam, A. 2003. Managing strategic innovation: An analysis of Dr. Reddy's laboratories. International Journal of Technology Management, 25: 247-267.

Bruton, G. D., Ahlstrom, D., \& Si, S. 2015. Entrepreneurship, poverty, and Asia: Moving beyond subsistence entrepreneurship. Asia Pacific Journal of Management, 32(1): 1-22.

Bruton, G. D., Ahlstrom, D., \& Singh, K. 2002. The impact of the institutional environment on the venture capital industry in Singapore. Venture Capital: An International Journal of Entrepreneurial Finance, 4(3): 197-218.

Bruton, G., Ahlstrom, D., \& Yeh, K. S. 2004. Understanding venture capital in East Asia: The impact of institutions on the industry today and tomorrow. Journal of World Business, 39(1): 72-88.

Chadha, A. 2009. Product cycles, innovation, and exports: A study of Indian pharmaceuticals. World Development, 37: 1478-1483.

Chakrabarti, A., \& Bhaumik, P. K. 2009. Internationalization of technology development in India. Journal of Indian Business Research, 1: 26-38.

Chakraborty, D., \& Kumar, A. 2013. Unraveling the success of India's IT-ITES industry: Can India sustain this success?. Journal of Information Technology Theory and Application, 14: 5-14.

Chaminade, C. 2011. Are knowledge bases enough? A comparative study of the geography of knowledge sources in China (Great Beijing) and India (Pune). European Planning Studies, 19: 1357-1373.

Chaminade, C., \& Vang, J. 2008. Globalisation of knowledge production and regional innovation policy: Supporting specialized hubs in the Bangalore software industry. Research Policy, 37: 1684-1696.

Chan, C. M., Makino, S., \& Isobe, T. 2010. Does sub-national region matter? Foreign affiliate performance in the U.S. and China. Strategic Management Journal, 31(11): 1226-1243.

Chandra, N., \& Krishna, V. V. 2010. Academia-industry links: Modes of knowledge transfer at the Indian Institutes of Technology. International Journal of Technology Transfer and Commercialisation, 9: 53-76.

Chari, M. D., \& Banalieva, E. R. 2015. How do pro-market reforms impact firm profitability? The case of India under reform. Journal of World Business, 50(2): 357-367.

Chataway, J., Tait, J., \& Wield, D. 2007. Frameworks for pharmaceutical innovation in developing countries-The case of Indian pharma. Technology Analysis \& Strategic Management, 19: 697-708.

Chaturvedi, K., Chataway, J., \& Wield, D. 2007. Policy, markets and knowledge: Strategic synergies in Indian pharmaceutical firms. Technology Analysis \& Strategic Management, 19: 565-588.

Chaudhuri, S. 1986. Technological innovation in a research laboratory in India: A case study. Research Policy, 15: 89-103.

Chidambaram, R. 2011. Research and innovation: An Indian perspective. Research-Technology Management, 54: $22-27$.

Chittoor, R., Sarkar, M. B., Ray, S., \& Aulakh, P. S. 2009. Third-world copycats to emerging multinationals: Institutional changes and organizational transformation in the Indian pharmaceutical industry. Organization Science, 20: 187-205.

Christensen, C. M. 2006. The ongoing process of building a theory of disruption. Journal of Product Innovation Management, 23(1): 39-55.

Christensen, C. M., \& Raynor, M. E. 2003. The innovator's solution: Creating and sustaining successful growth. Boston: Harvard Business School Press.

Cooke, F. L., \& Saini, D. S. 2015. From legalism to strategic HRM in India? Grievance management in transition. Asia Pacific Journal of Management, 32(3): 619-643.

Cooper, R. G. 2009. The state of product development. Research-Technology Management, 52(1): 6-7.

Crescenzi, R., Rodríguez-Pose, A., \& Storper, M. 2012. The territorial dynamics of innovation in China and India. Journal of Economic Geography, 12: 1055-1085. 
Crossan, M. M., \& Apaydin, M. 2010. A multi-dimensional framework of organizational innovation: A systematic review of the literature. Journal of Management Studies, 47: 1154-1191.

D’Costa, A. P., \& Sridharan, E. (Eds.). 2004. India in the global software industry: Innovation, firm strategies and development. Houndmills: Palgrave Macmillan.

Daft, R. L. 1982. Bureaucratic versus non-bureaucratic structure and the process of innovation and change. In S. B. Bacharach (Ed.). Research in the sociology of organizations, Vol. 1: 129-166. Greenwich: JAI Press.

Damanpour, E. 1991. Organizational innovations: A meta-analysis of effects of determinants and moderators. Academy of Management Journal, 34: 555-590.

Das, K. 2011. Indian rural clusters and innovation: Challenges for inclusion. Economics, Management and Financial Markets, 6(1): 283-301.

Das, P. 2004. Economic liberalisation and R\&D and innovation response of Indian public and private sector industries. International Journal of Management and Decision Making, 5(1): 76-92.

Deolalikar, A. B., \& Roller, L. 1989. Patenting by manufacturing firms in India: Its production A. Journal of Industrial Economics, 37(3): 303-314.

Desai, A. 1984. Achievements and limitations of India's Technological Capability. In M. Fransman \& K. King (Eds.). Technological capacity in the Third World[M]. London: Macmillan.

Desai, A. V. 1985. Market structure and technology: Their interdependence in Indian industry. Research Policy, 14(3): 161-170.

Dixit, G. K., \& Nanda, T. 2011. Strategic alignment of organizational culture and climate for stimulating innovation in SMEs. International Journal of Innovation, Management and Technology, 2: 77-85.

Dong, D., \& Saha, A. 1998. He came, he saw, (and) he waited: An empirical analysis of inertia in technology adoption. Applied Economics, 30: 893-905.

Downs, G. W., Jr., \& Mohr, L. B. 1976. Conceptual issues in the study of innovation. Administrative Science Quarterly, 21: 700-714.

Dubey, J., \& Dubey, R. 2010. Pharmaceutical innovation and generic challenge: Recent trends and causal factors. International Journal of Pharmaceutical and Healthcare Marketing, 4(2): 175-190.

Duran, P., Kammerlander, N., van Essen, M., \& Zellweger, T. 2015. Doing more with less: Innovation input and output in family firms. Academy of Management Journal. doi:10.5465/amj.2014.0424.

Fagerberg, J., Mowery, D. C., \& Nelson, R. R. (Eds.). 2006. The Oxford handbook of innovation. Oxford: Oxford University Press.

Fan, P. 2011. Innovation capacity and economic development: China and India. Economic Change and Restructuring, 44: 49-73.

Flores, M., Boër, C., Huber, C., Plüss, A., Schoch, R., \& Pouly, M. 2009. Universities as key enablers to develop new collaborative environments for innovation: Successful experiences from Switzerland and India. International Journal of Production Research, 47: 4935-4953.

Florida, R., \& Kenney, M. 1988. Venture capital and high technology entrepreneurship. Journal of Business Venturing, 3(4): 301-319.

Franco, E., Ray, S., \& Ray, P. K. 2011. Patterns of innovation practices of multinational-affiliates in emerging economies: Evidences from Brazil and India. World Development, 39: 1249-1260.

Fu, X., \& Zhang, J. 2011. Technology transfer, indigenous innovation and leapfrogging in green technology: The solar-PV industry in China and India. Journal of Chinese Economic and Business Studies, 9: 329347.

George, G., Rao-Nicholson, R., Corbishley, C., \& Bansal, R. 2015. Institutional entrepreneurship, governance, and poverty: Insights from emergency medical response services in India. Asia Pacific Journal of Management, 32(1): 39-65.

Giles, C. 2014. China poised to pass U.S. as world's leading economic power this year. Financial Times: Apr. 30. http://www.ft.com/cms/s/2/d79ffff8-cfb7-11e3-9b2b-00144feabdc0.html\#axzz3MvhAnnqj, Accessed Dec. 25, 2014.

Ginsberg, A., \& Venkatraman, N. 1985. Contingency perspectives of organizational strategy: A critical review of the empirical research. Academy of Management Review, 10: 421-434.

Gong, Y., Chow, I. H.-S., \& Ahlstrom, D. 2011. Cultural diversity in China: Dialect, job embeddedness, and turnover. Asia Pacific Journal of Management, 28(2): 221-238.

Gopalakrishnan, S., \& Damanpour, F. 1997. A review of innovation research in economics, sociology and technology management. Omega, 25: 15-28.

Goswami, S., \& Mathew, M. 2005. Definition of innovation revisited: An empirical study on India information technology industry. International Journal of Innovation Management, 9: 371-383. 
Govindarajan, V., Kopalle, P. K., \& Daneels, E. 2011. The effects of mainstream and emerging customer orientations on radical and disruptive innovations. Journal of Product Innovation Management, 28(s1): 121-132.

Govindarajan, V., \& Ramamurti, R. 2011. Reverse innovation, emerging markets, and global strategy. Global Strategy Journal, 1: 191-205.

Govindarajan, V., \& Ramamurti, R. 2013. Delivering world-class health care, affordably. Harvard Business Review, 91: 117-122.

Guennif, S., \& Ramani, S. V. 2012. Explaining divergence in catching-up in pharma between India and Brazil using the NSI framework. Research Policy, 41: 430-441.

Gupta, A. K., \& Govindarajan, V. 2001. Converting global presence into global competitive advantage. Academy of Management Executive, 15: 45-56.

Gupta, A. K., \& Wang, H. 2009. Getting China and India right: Strategies for leveraging the world's fastest growing economies for global advantage. San Francisco: Jossey-Bass, John Wiley \& Sons.

Haakonsson, S. J., Jensen, P. D. O., \& Mudambi, S. M. 2013. A co-evolutionary perspective on the drivers of international sourcing of pharmaceutical R\&D to India. Journal of Economic Geography, 13: 677-700.

Harding, H. 1987. China's second revolution: Reform after Mao. Washington, DC: Brookings Institution.

Hitt, M. A., Keats, B. W., \& DeMarie, S. M. 1998. Navigating in the new competitive landscape: Building strategic flexibility and competitive advantage in the 21 st century. Academy of Management Executive, 12(4): 22-42.

Hsu, P. 2009. Technological innovations and aggregate risk premiums. Journal of Financial Economics, 94: 264-279.

Jain, A., \& Kharbanda, V. P. 2003. Strengthening science and technology capacities for indigenisation of technology: The Indian experience. International Journal of Services, Technology and Management, 4: 234-254.

Jain, S. 2012. Pragmatic agency in technology standards setting: The case of Ethernet. Research Policy, 41(9): 1643-1654.

Jain, S., \& Sharma, D. 2013. Institutional logic migration and industry evolution in emerging economies: The case of telephony in India. Strategic Entrepreneurship Journal, 7: 252-271.

Jalan, B. 1996. India's Economic Policy: Preparing for the twenty-first century. New Delhi: Penguin.

Joseph, K. J., \& Abraham, V. 2009. University-industry interactions and innovation in India: Patterns, determinants, and effects in select industries. Seoul Journal of Economics, 22: 467-497.

Judge, W. Q., Fainshmidt, S., \& Brown, J. L., III. 2014. Which model of capitalism best delivers both wealth and equality?. Journal of International Business Studies, 45: 363-386.

Kale, D. 2010. The distinctive patterns of dynamic learning and inter-firm differences in the Indian pharmaceutical industry. British Journal of Management, 21: 223-238.

Kaplinsky, R. 2011. Schumacher meets Schumpeter: Appropriate technology below the radar. Research Policy, 40(2): 193-203.

Karna, A., Täube, F., \& Sonderegger, P. 2013. Evolution of innovation networks across geographical and organizational boundaries: A study of R\&D subsidiaries in the Bangalore IT cluster. European Management Review, 10: 211-226.

Kathuria, V. 2008. The impact of FDI inflows on R\&D investment by medium- and high-tech firms in India in the post-reform period. Transnational Corporations, 17: 45-66.

Khandwalla, P. 2014. Designing a creative and innovative India. International Journal of Human Resource Management, 25: 1417-1433.

Khanna, T. 2013. Billions of entrepreneurs: How China and India are reshaping their futures and yours. Boston: Harvard Business Press.

Khavul, S., Peterson, M., Mullens, D., \& Rasheed, A. A. 2010. Going global with innovations from emerging economies: Investment in customer support capabilities pays off. Journal of International Marketing, 18: $22-42$.

Kim, D., Basu, C., Naidu, G. M., \& Cavusgil, E. 2011. The innovativeness of born-globals and customer orientation: Learning from Indian born-globals. Journal of Business Research, 64: 879-886.

Kingston, W. 2013. Transforming the conditions for indigenous innovation. Economic and Social Review, 43: 631-651.

Koppman, S., \& Gupta, A. 2014. Navigating the mutual knowledge problem: A comparative case study of distributed work. Information Technology \& People, 27: 83-105.

Krishna, V. V. 2007. Large public research systems: India's CSIR, the CNRS in France and the CSIRO. Innovation: Management, Policy \& Practice, 9: 192-202.

Krishnan, R. T. 2012. Innovation strategies of Indian market leaders. Journal of Indian Business Research, 4: 92-96. 
Krishnaswamy, K. N., \& Kamala, G. V. 1979. An analysis of R\&D objectives in Indian manufacturing companies. R\&D Management, 9: 101-104.

Kulkarni, S. V. 2013. Innovation management-challenges and opportunities in the next decade. Asia Pacific Journal of Management \& Entrepreneurship Research, 2: 225-235.

Kumar, R. S., \& Subrahmanya, M. B. 2010. Influence of subcontracting on innovation and economic performance of SMEs in Indian automobile industry. Technovation, 30: 558-569.

Lam, A. 2000. Tacit knowledge, organizational learning and innovation: A societal perspective. Organization Studies, 21: 487-513.

Landes, D. S. 1998. The wealth and poverty of nations: Why some are so rich and some so poor. New York: W.W. Norton \& Company.

Lerner, J. 2009. Boulevard of broken dreams: Why public efforts to boost entrepreneurship and venture capital have failed - And what to do about it. Princeton: Princeton University Press.

Lewis, J. I. 2007. Technology acquisition and innovation in the developing world: Wind turbine development in China and India. Studies in Comparative International Development, 42: 208-232.

Li, P. P. (Ed.). 2013. Disruptive innovation in Chinese and Indian businesses: The strategic implications for local entrepreneurs and global incumbents. Abingdon: Routledge.

Li, S., \& Nair, A. 2007. A comparative study of the economic reforms in China and India: What can we learn?. Global Economic Review, 36: 147-166.

Liu, X., Kaza, S., Zhang, P., \& Chen, H. 2011. Determining inventor status and its effect on knowledge diffusion: A study on nanotechnology literature from China, Russia, and India. Journal of the American Society for Information Science and Technology, 62: 1166-1176.

Lockett, A., Wright, M., Sapienza, H., \& Pruthi, S. 2002. Venture capital investors, valuation and information: a comparative study of the U.S., Hong Kong, India and Singapore. Venture Capital, 4(3): 237-252.

Lodh, S., Nandy, M., \& Chen, J. 2014. Innovation and family ownership: Empirical evidence from India. Corporate Governance: An International Review, 22: 4-23.

Lynn, L., Meil, P., \& Salzman, H. 2012. Reshaping global technology development: Innovation and entrepreneurship in China and India. Journal of Asia Business Studies, 6: 143-159.

Maheshwari, S. K., \& Ahlstrom, D. 2004. Turning around a state owned enterprise: The case of Scooters India Limited. Asia Pacific Journal of Management, 21(1/2): 75-101.

Mahmood, I. P., \& Singh, J. 2003. Technological dynamism in Asia. Research Policy, 32: 1031-1054.

Maini, C. K. 2005. REVA electric car: A case study of innovation at RECC. International Journal of Technology Management, 32: 199-212.

Manimala, M. J., Jose, P. D., \& Thomas, K. R. 2006. Organizational constraints on innovation and intrapreneurship: Insights from public sector. Vikalpa, 31: 49-60.

Mathew, G. E. 2011. India's innovation blueprint: How the largest democracy is becoming an innovation superpower. Cambridge: Chandos.

Mathew, J., Ogbonna, E., \& Harris, L. C. 2012. Culture, employee work outcomes and performance: An empirical analysis of Indian software firms. Journal of World Business, 47: 194-203.

McCloskey, D. N. 2006. The bourgeois virtues: Ethics for an age of commerce. Chicago: University of Chicago Press.

McCloskey, D. N. 2010. Bourgeois dignity: Why economics can't explain the modern world. Chicago: University of Chicago Press.

McCloskey, D. N. 2013. Tunzelmann, Schumpeter, and the hockey stick. Research Policy, 42(10): 17061715.

McMahon, D., \& Thorsteinsdóttir, H. 2013. Pursuing endogenous high-tech innovation in developing countries: A look at regenerative medicine innovation in Brazil, China and India. Research Policy, 42: 965-974.

Mehra, K., \& Joshi, K. 2010. The enabling role of the public sector in innovation: A case study of drug development in India. Innovation: Management, Policy \& Practice, 12: 227-237.

Messner, W. 2011. Offshoring to India-Realising savings and capturing value. Journal of Indian Business Research, 3: 63-68.

Mishra, P. 2006. Mergers acquisition market structure and industry performance: Experience of Indian pharmaceutical industry. Review of Development and Change, 11: 135-164.

Mishra, P. 2010. R\&D efforts by Indian pharmaceutical firms in the new patent regime. South East European Journal of Economics and Business, 5: 83-94.

Misra, S. D. 2007. R\&D intensity and market structure: A study of the Indian manufacturing sector. International Journal of Economic Perspectives, 1: 217-227.

Mokyr, J. 1990. The lever of riches: Technological creativity and economic progress. Oxford: Oxford University Press. 
Nair, A., \& Ahlstrom, D. 2003. Delayed creative destruction and the coexistence of technologies. Journal of Engineering and Technology Management, 20(4): 345-365.

Nair, A., Ahlstrom, D., \& Filer, L. 2007. Localized advantage in a global economy: The case of Bangalore. Thunderbird International Business Review, 49(5): 591-618.

Pai, D. C., Tseng, C. Y., \& Liou, C. H. 2012. Collaborative innovation in emerging economies: Case of India and China. Innovation: Management, Policy \& Practice, 14: 467-476.

Parente, S. L., \& Prescott, E. C. 2002. Barriers to riches. Cambridge: MIT Press.

Petroski, H. 1994. The evolution of useful things: How everyday artifacts-from forks and pins to paper clips and zippers - came to be as they are. New York: Vintage Books.

Plechero, M., \& Chaminade, C. 2013. The influence of micro-characteristics in different modes of globalization of innovation: A comparative study of Indian (Pune) and Chinese (Beijing) firms. Industry and Innovation, 20: 661-682.

Popkin, J. M., \& Iyengar, P. 2007. IT and the East: How China and India are altering the future of technology and innovation. Boston: Harvard Business School Press.

Porter, M. E. 1990. Competitive advantage of nations. New York: Free Press.

Prabhu, J., \& Jain, S. 2015. Innovation and entrepreneurship in India: Understanding jugaad. Asia Pacific Journal of Management, this issue.

Prahalad, C. K., \& Mashelkar, R. A. 2010. Innovation's holy grail. Harvard Business Review, 88(7-8): 132141.

Prakash, Y., \& Gupta, M. 2008. Exploring the relationship between organisation structure and perceived innovation in the manufacturing sector of India. Singapore Management Review, 30: 55-76.

Prasad Mohanty, R., \& Augustin, P. 2014. Business strategy of automotive and farm equipment sector of the Mahindra \& Mahindra Group of India. Journal of Strategy and Management, 7: 64-86.

Rai, S. 2014. From India, proof that a trip to Mars doesn't have to break the bank. New York Times: Feb. 17.

Rai, S., Pedersen, M. K., \& Kazakevičiūtè, A. 2010. A framework for the co-creation of ICT innovation: Empirical results from India. Journal of Information Technology Case and Application Research, 12(4): 13-36.

Raina, R. S. 2003. Institutions and organisations enabling reforms in Indian agricultural research and policy. International Journal of Technology Management and Sustainable Development, 2(2): 97-116.

Ramani, S. V., \& Szirmai, A. 2014. Innovation in India: The challenge of combining economic growth with inclusive development. In S. V. Ramani (Ed.). Innovation in India: Combining economic growth with inclusive development: 1-38. Cambridge: Cambridge University Press.

Ramesh, J. 1991. Commanding heights. Interview with PBS. http://www.pbs.org/wgbh/commandingheights.

Ravishankar, M. N. 2013. Public ICT innovations: A strategic ambiguity perspective. Journal of Information Technology, 28: 316-332.

Reddy, P. 1997. New trends in globalization of corporate R\&D and implications for innovation capability in host countries: A survey from India. World Development, 25: 1821-1837.

Reece, J. D. 2007. What enables innovation in the private sector? Lessons from the development of salttolerant hybrid rice. Journal of International Development, 19: 853-863.

Richman, B. D., Udayakumar, K., Mitchell, W., \& Schulman, K. A. 2008. Lessons from India in organizational innovation: A tale of two heart hospitals. Health Affairs, 27: 1260-1270.

Rodrik, D., Subramanian, A., \& Trebbi, F. 2004. Institutions rule: The primacy of institutions over geography and integration in economic development. Journal of Economic Growth, 9(2): 131-165.

Roy, A., \& Gupta, R. K. 2007. Knowledge processes in small manufacturing. Journal of Entrepreneurship, 16: 77-93.

Roy, S., \& Banerjee, P. 2011. Intercity differences in university, R\&D and industry interactions in biomedical sector research in India. International Journal of Technology Management and Sustainable Development, 10: $27-44$.

Roy, S., \& Wilkinson, I. 2004. International long term business relationship, communities of practice and innovation: A longitudinal case study of NDDB, India and Tetra Pak, Sweden. International Journal of Technology Transfer and Commercialisation, 3: 454-469.

Russell, L. R. 2008. Training for innovation in India: Cultural considerations and strategic implications. Performance Improvement Quarterly, 21: 37-48.

Sahoo, A., \& Shrimali, G. 2013. The effectiveness of domestic content criteria in India's solar mission. Energy Policy, 62: 1470-1480. 
Samii, R., Van Wassenhove, L. N., \& Bhattacharya, S. 2002. An innovative public-private partnership: New approach to development. World Development, 30(6): 991-1008.

Sampath, P. G. 2006. India's product patent protection regime: Less or more of "Pills for the Poor"?. Journal of World Intellectual Property, 9: 694-726.

Schneider, M. R., \& Paunescu, M. 2012. Changing varieties of capitalism and revealed comparative advantages from 1990 to 2005: A test of the Hall and Soskice claims. Socio-Economic Review, 10(4): $731-753$.

Schrage, M. 2011. Global innovators from emerging markets. Research-Technology Management, 54: 10-11.

Schreiner, S. T., \& Lerman, N. M. 2013. Using patents to protect financial process innovations in Europe, China, and India. Banking Law Journal, 130: 496.

Schumpeter, J. 1934. Theory of economic development. Cambridge: Harvard University Press.

Schumpeter, J. 1942. Capitalism, socialism, and democracy. New York: Harper \& Row.

Sen, F., \& Rubenstein, A. H. 1989. External technology and in-house R\&D's facilitative role. Journal of Product Innovation Management, 6: 123-138.

Seshadri, D. V. R., Kommi, C. K., \& Ray, S. 2006. Creating a crucible of innovation at trilogy India. South Asian Journal of Management, 13: 112-128.

Shafique, M. 2013. Thinking inside the box? Intellectual structure of the knowledge base of innovation research (1988-2008). Strategic Management Journal, 34: 62-93.

Sharma, P., Nookala, S. B. S., \& Sharma, A. 2012. India's national and regional innovation systems: Challenges, opportunities and recommendations for policy makers. Industry and Innovation, 19: 517-537.

Sikka, P. 1999. Technological innovations by SME's in India. Technovation, 19: 317-321.

Singh, S. 2006. Big players in chip design buy into India. IEEE Spectrum, 43: 14-17.

Smith, A. 1776/1937. The wealth of nations. New York: Modern Library.

Som, A. 2006. Bracing for MNC competition through innovative HRM practices: The way ahead for Indian firms. Thunderbird International Business Review, 48: 207-237.

Subrahmanya, M. 2005. Pattern of technological innovations in small enterprises: A comparative perspective of Bangalore (India) and Northeast England (UK). Technovation, 25: 269-280.

Subrahmanya, M. 2007. Development strategies for Indian SMEs: Promoting linkages with global transnational corporations. Management Research News, 30: 762-774.

Subrahmanya, M. 2009. Nature and strategy of product innovations in SMEs: A case study-based comparative perspective of Japan and India. Innovation: Management, Policy \& Practice, 11: 104-113.

Tansuhaj, P., Gentry, J. W., John, J., Lee Manzer, L., \& Jin Cho, B. 1991. A cross-national examination of innovation resistance. International Marketing Review, 8: 7-20.

Tarafdar, M., Singh, R., \& Anekal, P. 2013. Impact of ICT-enabled product and process innovations at the bottom of the pyramid: A market separations perspective. Journal of Information Technology, 28: 279295.

Thakur, R., \& Hale, D. 2013. Service innovation: A comparative study of U.S. and Indian service firms. Journal of Business Research, 66: 1108-1123.

Thompson, V. 1965. Bureaucracy and innovation. Administrative Science Quarterly, 10: 1-20.

Tiwari, R., \& Herstatt, C. 2012. India-A lead market for frugal innovations? Extending the lead market theory to emerging economies. Working paper no. 67, Technologie- und Innovations management, Technische Universität Hamburg-Harburg.

Tseng, C. Y. 2009. Technological innovation in the BRIC economies. Research-Technology Management, 52: 29-35.

Velu, C., \& Khanna, M. 2013. Business model innovation in India. Journal of Indian Business Research, 5: 156-170.

Veng Søberg, P. 2011. The transfer and creation of knowledge within foreign invested R\&D in emerging markets. Journal of Technology Management in China, 6: 203-215.

Wang, L. C., Ahlstrom, D., Nair, A., \& Hang, R. Z. 2008. Creating globally competitive and innovative products: China's next Olympic challenge. SAM Advanced Management Journal, 73(3): 4-15.

Waychal, P., Mohanty, R. P., \& Verma, A. 2011. Determinants of innovation as a competence: An empirical study. International Journal of Business Innovation and Research, 5: 192-211.

Wolfe, R. A. 1994. Organizational innovation: Review, critique and suggested research directions. Journal of Management Studies, 31: 405-431.

Zhao, M. 2006. Conducting R\&D in countries with weak intellectual property rights protection. Management Science, 52: 1185-1199. 
Anil Nair (PhD, New York University) is a professor at the Strome College of Business, Old Dominion University. His research interests include competitive strategy, risk, innovation, and entrepreneurship. He has published over two dozen articles in journals such as the Strategic Management Journal, Management International Review, Long Range Planning, and Asia Pacific Journal of Management.

Orhun Guldiken (PhD Candidate, Strome College of Business, Old Dominion University) is interested in corporate governance, international entrepreneurship/innovation, and resource-based theory. His work has been published or is forthcoming in the Asia Pacific Journal of Management and Management International Review. He has received best paper awards at the Academy of Management and Southern Management Association. He presented his academic work at the annual meetings of Academy of Management, Strategic Management Society, Academy of International Business, Southern Management Association, and Babson College Entrepreneurship Research Conference.

Stav Fainshmidt ( $\mathrm{PhD}$, Strome College of Business, Old Dominion University) is an assistant professor of international business and strategy in the College of Business at Florida International University. His research focuses on institutions and governance, organizational capabilities, and methods in organizational research. His research has appeared in the Journal of International Business Studies, Journal of International Management, Strategic Management Journal, British Journal of Management, International Business Review, Managerial and Decision Economics, Journal of Trust Research, and Group \& Organization Management.

Amir Pezeshkan ( $\mathrm{PhD}$, Strome College of Business, Old Dominion University) is an assistant professor at University of Baltimore, Merrick School of Business. He received his $\mathrm{PhD}$ in Strategic Management and International Business. His research interests are international venture capital firms' strategic behavior and performance, global strategy in emerging economies context, organizational capabilities, and strategic entrepreneurship. His research has been published in the South Asian Journal of Global Business Research, VINE, and presented at the annual meetings of Academy of Management and Southern Management Association. 